\title{
Low-Frequency Noise and Its Main Effects on Human Health-A Review of the Literature between 2016 and 2019
}

\author{
Juliana Araújo Alves 1,*D, Filipa Neto Paiva ${ }^{2}$, Lígia Torres Silva ${ }^{2}(\mathbb{D})$ and Paula Remoaldo ${ }^{1}$ \\ 1 Lab2PT-Landscape, Heritage and Territory Laboratory, University of Minho, 4710-057 Braga, Portugal; \\ premoaldo@geografia.uminho.pt \\ 2 CTAC-Centre for Territory, Environment and Construction, University of Minho, \\ 4800-058 Guimarães, Portugal; filipa_paiva@sapo.pt (F.N.P.); lsilva@civil.uminho.pt (L.T.S.) \\ * Correspondence: jalves.geografia@gmail.com
}

Received: 5 July 2020; Accepted: 27 July 2020; Published: 28 July 2020

\begin{abstract}
This paper summarizes the presently available knowledge about the association between low-frequency noise and its effects on health. A database was constructed with a total of 142 articles published between 2016 and 2019 regarding low-frequency noise exposure and its effects on health. A total of 39 articles were analysed in depth. The articles were divided into categories according to the effects on human health addressed. Regarding the emitting source, there was a greater number of articles addressing issues related to sources of environmental noise and noise from wind turbines. As for the effects generated on human health, there was a greater number of articles referring to the effects on sleep disorders, discomfort, sensitivity to and irritability from noise, annoyance, hearing loss, and cardiovascular diseases, and these effects are analysed in more detail in the present article.
\end{abstract}

Keywords: low-frequency noise; human health; impacts; environment; literature review

\section{Introduction}

At the worldwide level, there is a large number of studies on health impacts due to occupational and environmental exposure to noise. However, there are still few studies focusing exclusively on health impacts and discomfort due to low-frequency noise (Figure 1). One of the main reasons for this is the low sensitivity of the human auditory system to low frequencies. On the other hand, this type of noise has very particular characteristics and causes much more discomfort and long-term, non-auditory effects [1-3].

In the 1920s, research on the subject focused on occupational exposure and generally reported physiological changes such as pain in the hands, swelling, and increased vascular tone [4-6]. Until the 1930s, it was believed that the effects of noise on health were restricted only to hearing loss. In a study published in the Journal of the Acoustical Society of America, Jüichi Obata et al. [7] concluded that the effects of noise on human health went beyond hearing loss.

After the low contribution to the improvement of this scientific field in the 1960s, the 1970s were marked by the emergence of a series of studies addressing annoyance caused by environmental noise [1].

Consequently, during the 1970s and 1980s, studies started focusing on the impacts due to exposure to environmental noise [8,9]. The 1990s were marked by research aimed at more specific impacts on human health and reported discomfort due to noise [9-11]. Furthermore, these studies correlated exposure to noise with the onset of cardiovascular diseases [12,13].

In the 1990s, the World Health Organization (WHO) published documents on the subject, such as the Guidelines for Community Noise, in 1999. Regarding the studies published during the 2000s, 
the most important are those directed at specific environments, such as schools and residential areas $[14,15]$. These studies used a comparison of the noise level measured by using reference curves with the aim of assessing noise discomfort and reinforced the fact that the A-weighting filter is not ideal to evaluate the non-auditory effects of low-frequency noise (LFN) [1-3]. From 2005, the studies that stand out are oriented to the impacts of low-frequency noise on the quality of sleep [16-18].

In general, these studies were carried out with voluminous samples involving patient reports, the application of questionnaires, the adoption of cross-sectional studies based on databases, and the comparison of environmental noise levels measured using criteria curves.

In fact, these studies reinforced the fact that low-frequency noise is a powerful stressor. The most cited effects on human health refer to emotional changes such as annoyance [19,20], agitation, and distraction [2,21,22], in addition to the association of low-frequency noise with cognitive alterations [23], the development of cardiovascular diseases [24,25], sleep disorders [26], and high blood pressure [27], and, more recently, the effects of industrial low-frequency noise on dental wear [28,29].

In the field of occupational medicine, there is a large number of studies that claim that low-frequency noise is an agent that interferes with the performance of work tasks [22,30]. In addition to these changes, noise can be an agent that affects mental and physical health.

In this sense, the effects of noise pollution comprise "auditory effects", which directly affect the human auditory system, and "non-auditory effects", i.e., the impact of noise on physiological functions. As regards "non-hearing effects", discomfort has been reported as the most frequent effect caused by exposure to low-frequency noise in humans $[1,31,32]$.

In addition, the discomfort may vary from individual to individual and depends not only on the recorded noise pressure levels but also on the exposure time as well as the low-frequency components present in the measured sound levels. Thus, noise that contains low-frequency components tends to be more annoying than noise without them [1,33-35].

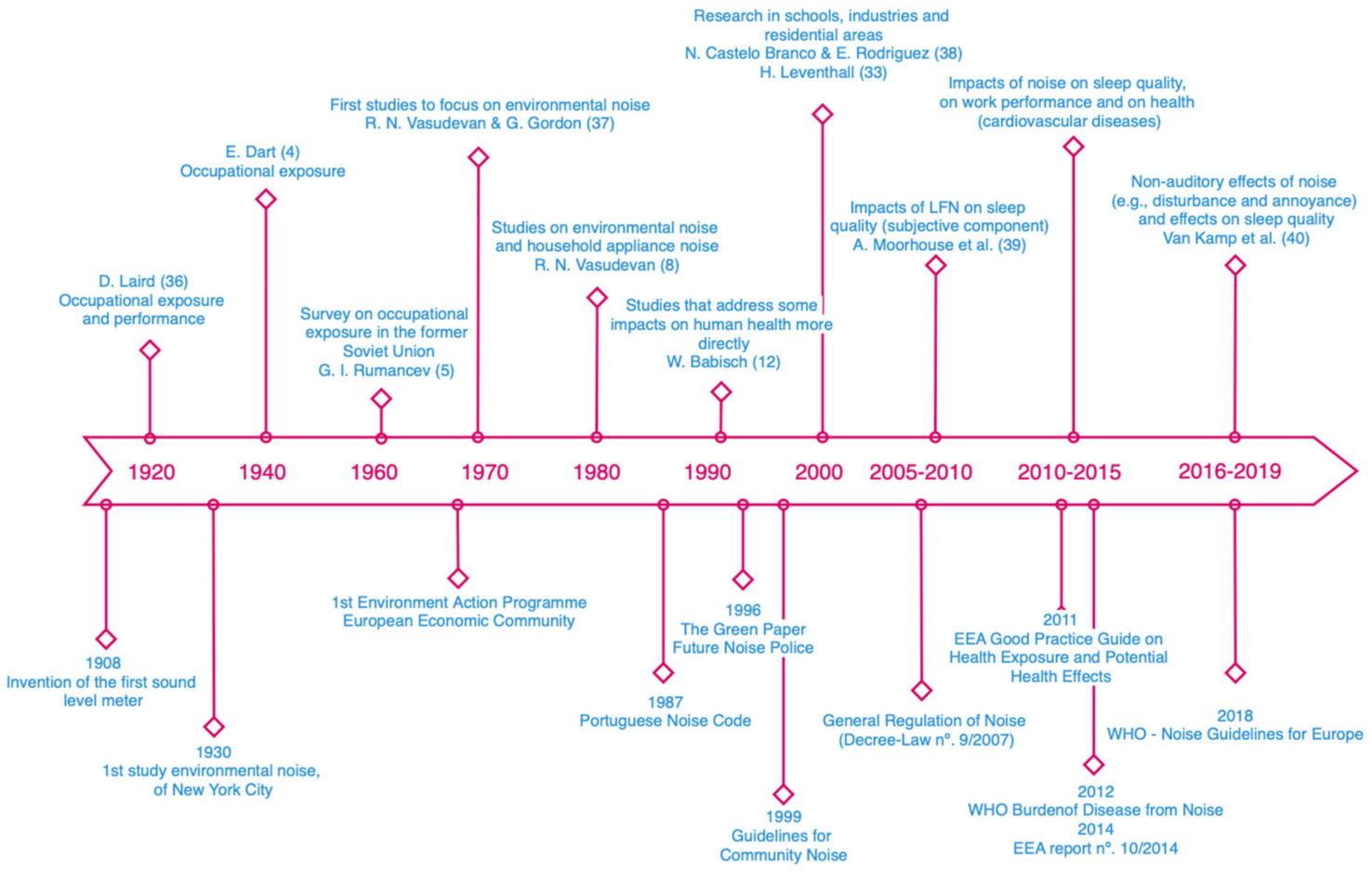

Figure 1. A summary regarding health effects due to low-frequency noise exposure. Source: own elaboration based on several authors $[4,5,8,12,36-40]$.

Since 2000, the WHO has recognized low-frequency noise as an environmental problem. In addition, the health impacts of low-frequency components on noise are estimated to be more severe [1,33-35]. 
The WHO published its most recent noise pollution guidelines for Europe in 2018. This publication states that further research into the health impacts from wind turbine noise is needed, namely, the low-frequency component [35].

In fact, a systematic review of the up-to-date, peer-reviewed, epidemiological literature has been performed on the association between low-frequency noise and its effects on human health. The present paper aims to fill this gap in the literature.

The paper is structured into four sections. After the introduction, the methodology is outlined. A systematic review regarding scientific articles about low-frequency noise and its impacts on human health is presented in Section 3. The article concludes by highlighting the main conclusions of an in-depth analysis of 39 articles published between 2016 and 2019, some limitations of the research, and recommendations for further studies.

\section{Materials and Methods}

\section{Database Collection}

The original papers were identified by a literature search between October and December 2019 of all of the principal accessible journals and databases (PubMed, Web of Science, and Scopus) concerning the theme and using the following keywords: "low-frequency noise"; "low-frequency noise and its effects on health"; "noise pollution and health". A database was constructed with some variables, e.g., sample results and main noise sources. A total of 142 articles published between 2016 and 2019 was found (Supplementary Materials). Only studies were included in which it was mentioned in the title or abstract that the association between the low-frequency noise and effects concerning health or well-being was studied.

The 142 papers selected for the period from January 2016 to December 2019 were grouped into 9 categories: reviews; health effects due to noise and noise pollution; low-frequency sound/infrasound; health LFN case studies (small population); health LFN case studies (large population); LFN case studies (animals); laboratories studies, simulation studies, and computational case studies; and not relevant. A total of 39 articles published between 2016 and 2019 and grouped in the categories "health LFN case studies (small population)", "health LFN case studies (large population)", and, finally, "LFN case studies (animals)" were selected for in-depth evaluation. The evaluation carried out focused on the impacts on health, highlighting the incidence of studies aimed at human health and others aimed at carrying out tests on animals that may lead to a future study on humans. Additionally, the 39 articles evaluated used similar techniques (e.g., questionnaires; data previously collected in other studies; cognitive, physiological, and psychological tests based on medical and auditory equipment; noise measurements and audiometric assessments; and experimental tests based on noise exposure). The 39 articles evaluated were carried out mostly in Asian and European countries and were based on small samples.

\section{Results and Discussion}

This section presents the main results obtained from the analysis of articles published on low-frequency noise and its impacts on human health between 2016 and 2019. The results and discussion are structured in five sections on the main effects of low-frequency noise exposure on human health. Each section begins with a description of the methodologies used, followed by the main results achieved in the studies analysed.

\subsection{Low-Frequency Noise Exposure and Its Main Health Effects}

Table 1 presents a synthesis of the 39 articles based on three of the categories listed in the methodology section. These categories were as follows: cases of low-frequency noise studies in a small population, in a large population, and in a population of animals. 
Of the 39 articles that were included in the evaluation of this article, it was observed that the main effects on human health are more prevalent in aspects such as sleep disorders $(11.7 \%)$, discomfort, sensitivity and irritability to noise $(10 \%)$, annoyance $(13.3 \%)$, stress $(6.7 \%)$, hearing loss $(8.3 \%)$, reduced performance/fatigue (5\%), heart rate/cardiovascular diseases $(10 \%)$, tension and blood pressure $(6.7 \%)$, anxiety $(1.7 \%)$, depression $(3.3 \%)$, imbalance $(3.3 \%)$, and mental performance $(6.7 \%)$.

There were also other effects on human health but with an incidence in very specific aspects $(13.3 \%)$, such as the frequency of chromosomal aberrations in bone marrow cells, excess bilirubin, peptic ulcers (gastric and duodenal), effects on the cerebral blood barrier, haemodynamic events, irreversible imbalance with structural damage to the otoconial membrane, tinnitus and sound reconversion therapy, and vocal disorders and effort.

Only the effects on human health related to sleep disturbance, noise discomfort, annoyance, hearing loss, and cardiovascular disease were analysed, as these were the themes where a greater number of articles were observed, thus allowing a better comparison and evaluation between the various articles.

\subsection{Sleep Disturbance}

Sleep disturbance is one of the effects on human health that is due to exposure to noise, in particular, low-frequency noise. Long-term exposure to low-frequency noise from wind energy is a major factor in sleep disturbances in residents who live near wind farms. Abbasi et al. [41], Morsing et al. [42], Ishitake [43], Pohl, Gabriel, and Hübner [44], and Poulsen et al. [45] evaluated exposure to low-frequency noise due to proximity to wind turbines. The methodology adopted included the measurement of sound levels and, after the exposure of participants to wind turbine noise, an assessment of sleep disturbances.

The studies [41-43] applied questionnaires to participants to assess the disturbances they felt after exposure to noise. In the study by Abbasi et al. [41], in addition to the questionnaire, Pearson's correlation, analysis of variance, and multiple regression tests were applied for data analysis using software. Morsing et al. [42] evaluated the impact of noise on sleep as measured by polysomnography, after participants were exposed to wind turbine noise for three consecutive nights. Finally, Ishitake [43] assessed sleep disorders using the Athens Insomnia Scale method, based on the responses of participants when exposed to noise.

In the study designed by Pohl, Gabriel, and Hübner [44], the methodology of stress psychology with noise measurement was adopted, ascertaining the physical and psychological symptoms referenced by residents that participated in the study (general mental indisposition, performance and reduced work capacity, lack of concentration, fatigue, tension, nervousness, negative mood, dizziness, irritability, indisposition, reduced sleep quality, and annoyance) caused by exposure to noise from wind turbines. Moreover, Poulsen et al. [45] evaluated the evolution of medical prescriptions related to anxiolytics and antidepressants ingested by the populations living near the wind turbines, in an analysis that lasted two years (2012 to 2014).

Sleep disturbances may also be due to exposure to noise from oil and gas operations, namely in the construction and drilling of wells in residential areas [46]. Blair et al. [46] evaluated the impacts of these operations on human health, including sleep disorders. Sleep disturbances can also be linked to exposure to railway noise, as studied by Smith et al. [47]. They [47] evaluated the effects on physiological sleep resulting from the exposure of participants to railway noise for five consecutive nights, using polysomnography and questionnaires.

As for the results, Abbasi et al. [41] evaluated the effects of noise from wind turbines on the health of employees, divided into three groups (maintenance, safety, and administration). The group with the greatest exposure to noise was the maintenance team, who were considered as a reference group. Maintenance workers were subject to a higher sound level because they are in the vicinity of wind turbines, and higher GHQ (The General Health Questionnaire) scores were also recorded (the health assessment tool for individuals used in the study). Therefore, compared to those on management and safety staff, the harmful health effects of wind turbine noise are stronger on maintenance workers. 
The questionnaire was divided into four sections, including somatic symptoms, anxiety and insomnia, social dysfunction, and depression. Based on the results obtained in this study, only the equivalent sound level had a significant effect on the general state of health and in some of its sections. The negative impact of noise exposure of 60 and $66 \mathrm{dBA}$ on general health was approximately six and four times less than that of $83 \mathrm{dBA}$, respectively. The adverse effect of $60 \mathrm{dBA}$ noise exposure in the anxiety and insomnia section was 1.6 times less than that in the $83 \mathrm{dBA}$ exposure group. The effect of the experiment in the anxiety and insomnia section was 0.2 times greater than that of the $83 \mathrm{dBA}$ noise exposure. This result indicates that the worst health status is due to working conditions and chronic exposure to occupational risk factors, such as noise. The results show that the effect of exposure to noise of $66 \mathrm{dBA}$ in the social dysfunction section was 2.3 times less than that of $83 \mathrm{dBA}$ noise. It was concluded that exposure to noise is significantly correlated with all subsections of general health, except depression. As a general evaluation of the article, the low-frequency noise from the turbines can cause harmful effects on the health of workers who are very close to the turbine, due to the reception of very intense noise [41]. By convention, a frequency A-weighting filter is used in low-frequency noise evaluation [3]. As a matter of fact, the A-weighting filter is not suitable for assessing the effects of low-frequency noise because this filter drastically reduces the low-frequency levels measured [3].

The results obtained by Morsing et al. [42] are due to the measurement of the effects of night noise from wind turbines on sleep measured physiologically in the laboratory. During nights with noise from the turbines, there was some incidence of participants with frequent awakening, less deep sleep, reduced continuous sleep, an increase in sleep disorders self-reported by the participants, and morning tiredness after the nights of noise exposure compared to nights without exposure to noise. Some evidence was observed in the study in which amplitude modulation and rotational frequency were varied; deeper sleep was negatively affected due to higher frequency and strong amplitude modulation while light sleep increased with high frequency and acoustic beat [42].

Blair et al. [46] monitored continuous levels of audible and low-frequency noise during the construction and drilling of oil and gas wells in a residential area. The equivalent monthly levels of continuous noise varied between minimum values of 51.5 and $73.1 \mathrm{dBC}$, and maximum values of 60.2 to $80.0 \mathrm{dBC}$. On the one hand, Blair et al. [46] found that continuous weighted noise levels above $50 \mathrm{dBA}$ can have effects on health, such as increasing the risk of cardiovascular disease and hypertension. On the other hand, they found that low-frequency noise levels that exceeded the recommended level of $60 \mathrm{dBC}$ caused nausea and headaches. In a general analysis of the article, the average noise levels in an oil and gas well during construction and drilling exceeded the levels associated with annoyance, sleep disturbances, and cardiovascular health effects; that is, they were higher than $50 \mathrm{dBA}$ or $60 \mathrm{dBC}$ [46].

Ishitake [43] conducted an epidemiological study that suggests that the noise generated by wind power generation facilities may be a risk factor for effects on human health, especially sleep disturbances. In this study regarding sleep disturbances caused by infrasound, it was found that the noise level of the wind turbine measured in the lower frequency range is below the human sensory threshold. As mentioned by Ishitake, $63 \%$ reported having sleep disturbance; the effect was reduced with increased distance between the source and the receiver [43].

Pohl, Gabriel, and Hübner [44] carried out a study that combined the methodology of stress psychology with noise measurement. They conducted interviews with residents who lived close to a wind farm and assessed their perception of noise from the wind farm and road traffic at two different points in time, first in 2012 and later in 2014. Residents complained of physical and psychological symptoms due to traffic noise $(16 \%)$ and noise from wind turbines $(10 \%$ and $7 \%$ in 2012 and 2014 , respectively). In the study, 12 symptoms caused by exposure to noise were evaluated. It was found that the participants reported more symptoms in 2012 than in 2014 and the most strongly irritated participants considered their overall health in 2014 to be improved. The sleep disorders assessed decreased from 2012 to 2014. Distraction also decreased slightly from 2012 to 2014 for the most irritated residents, while remaining relatively low and/or unchanged in the other groups. However, only a few participants showed evidence of noise from low-frequency wind turbines: in 2012, 8.5\% reported 
feelings of pressure related to wind farms and 6.1\% reported having felt vibrations in the body; in 2014, these feelings decreased to $6.8 \%$ and $3.8 \%$, respectively. The annoyance experienced was very low, and symptoms of dizziness were not observed in this study. Regarding the effects of wind noise stress compared to road traffic noise, there were more reports of symptoms due to traffic $(15.8 \%)$ than to noise from wind turbines. In 2014, it was observed that about a third (34.9\%) of the participants were slightly irritated by traffic noise and $21.2 \%$, by noise from the wind farm [44].

Poulsen et al. [45] determined the numbers of prescriptions for anxiolytics and antidepressants for residents due to prolonged exposure to noise from wind turbines. During the survey carried out between 1996 and 2013, 68,696 adults had recourse to sleeping pills and 82,373 used antidepressants, out of a population of 583,968 and 584,891 , respectively. In this study, it was observed that people over the age of 65 years were more affected by the noise of wind turbines, with an HR (hazard ratio) of 1.68 for measuring sleep and 1.23 for antidepressants being found for the group with the greatest exposure. Regarding low-frequency noise due to wind turbines in indoor environments, the risk rate among people aged 65 and over when exposed to noise equal to or higher than $15 \mathrm{~dB}$ was 1.37 for anxiolytics and 1.34 for antidepressants. Thus, Poulsen et al. [45] concluded that the combination of high noise levels from wind turbines and the use of anxiolytics and antidepressants can induce sleep disturbance and, in turn, affect the mental health of the elderly [45].

Finally, Smith et al. [47] demonstrated that sleep was significantly affected, both in terms of physiological measures and by self-report, during nights with exposure to $45 \mathrm{~dB}$ noise, although the number and size of the effects were modest. Most self-reported sleep measures were adversely affected by terrestrial railway noise. In this study, no significant differences were found in the general sleep structure or disorders and in the subjective quality of sleep between the reference tests and the $35 \mathrm{~dB}$ night tests. The results obtained support the value of the Swedish guidelines proposed for the maximum noise level of $35 \mathrm{~dB}$ for indoor environments and may be suitable for protection against adverse sleep problems due to terrestrial railway noise [47].

\subsection{Discomfort from, Sensitivity to, and Irritability from Noise}

Discomfort, sensitivity to noise, and irritability are other effects on human health due to exposure to low-frequency noise.

Huang, Pan, Liu, Hou, and Yang [48] analysed acoustic comfort and developed a noise analysis model for a skyscraper by measuring exterior noise, mainly from road traffic.

Suzuki, Suzuki, Onishi, and Penido [49] performed audiometric assessments on patients with persistent tinnitus, through their perception of sounds of nature and everyday life and their comparison with a pure tone or noise (white noise, narrow-band low frequency and narrow-band high frequency). The assessments considered in the patients were otorhinolaryngological, audiological, Pitch Matching and Loudness, Visual Analogue Scale, Tinnitus Handicap Inventory, and Minimum Masking Level [49].

Lee et al. [50] determined the effects of exposure to transport noise and established a relationship with the blood pressure of residents of residential buildings. They determined noise exposure levels (Lden, Lday, and Lnight) through adjusted linear regression analysis and established the relationship with blood pressure [50]. They also conducted a questionnaire related to the annoyance caused by internal noise, noise sensitivity, and sociodemographic variables [50].

Tao, Wang, Zou, Li, and Luo [51] assessed the irritation from noise in a metro depot and the influence of noise in adjacent residential buildings. They carried out a questionnaire with people working at the metro station and took field measurements, both at the metro station and in the adjacent residential buildings [51].

Moradi et al. [52] studied the effects of noise on the selective attention of university students. They conducted questionnaires to determine students' personality traits; that is, they assessed whether they were extroverted or introverted and analysed their stability or instability [52]. In addition, they also assessed the level of sensitivity to noise using the Weinstein sensitivity scale and the level of selective attention using the DUAF test from the Vienna Test System [52]. 
Alves, Silva, and Remoaldo [53] analysed the effects of exposure to low-frequency noise pollution emitted by poles and power lines on the well-being of the population, based on a study carried out on "exposed" and "unexposed" populations in two residential areas. Additionally, adapted audiometric tests were carried out to complement the analysis and determine the audibility thresholds of "exposed" and "unexposed" volunteers. To develop the research, Alves, Silva, and Remoaldo [53] used sound level measurements and sound recordings (recordings made at a distance of $5 \mathrm{~m}$ from the source), as well as the adapted audiometric performance test [53].

Regarding the results, [48] observed that, due to the effect of the ground, the effect of medium propagation, and the different frequency components, the comfort of the sound does not increase with distance from the ground, that is, on the highest floors. They concluded that low-frequency noise has great potential for the annoyance and discomfort of the residents of the building.

Suzuki et al. [49] identified 181 tinnitus complaints in which pure-tone-type tinnitus was observed in 93 (51\%) of the responses (4 low pitch and 89 high pitch) and from noise in 88 (49\%) responses (15 low frequency and 73 high frequency). Regarding tinnitus with a low-frequency sensation, 19 responses were determined, while for that with a high-frequency sensation, 162 responses were found. They determined a Visual Analogue Scale average of 5.47 for tinnitus similar to pure tone and 6.66 for that similar to noise, with a higher value for noise. The average loudness of tinnitus similar to pure tone was $12.31 \mathrm{dBNS}$, and that similar to noise was $10.54 \mathrm{dBNS}$. For the Tinnitus Handicap Inventory and the Minimum Masking Level, the patients considered in the study were separated into three groups with tinnitus, pure tone, noise, and multiple, with the mean of the largest Tinnitus Handicap Inventory in the group with multiple tinnitus being 61.38. For the Minimum Masking Level, masked noises of the type white noise and narrow band [49] were used.

Lee et al. [50] concluded that general noise (road and rail traffic) and road traffic showed higher associations with systolic blood pressure (SBP) than with diastolic blood pressure (DBP), while rail noise had similar associations with SBP and DBP. They also observed that the closest associations between exposure to noise and blood pressure were estimated for participants who reported higher classifications of annoyance, irritation, and sensitivity to noise. This indicates that the annoyance of internal noise and sensitivity to noise develop regardless of the level of exposure to external noise. They also found that people who were sensitive to noise and participants who were most irritated due to internal noise had significantly higher SBP and DBP than the rest. In addition, the regression coefficients between noise exposure and blood pressure increased slightly in a subgroup that excluded participants exposed to high railway noise [50]. The results established by Lee et al. [50] support the hypothesis that long-term exposure to transport noise is associated with higher blood pressure in adults living in multi-storey residential buildings.

Tao et al. [51] concluded that $96 \%$ of respondents feel disturbed by noise and $31 \%$ of them feel that the impact of noise is serious. They noted that closing doors in buildings may be a solution, but only a reduction in noise from the low-frequency structure in the range 63 to $125 \mathrm{~Hz}$ occurs. They found that there is a problem of annoyance from low-frequency noise. They evaluated that the noise level caused by the fans decreases with the height of the floors. Ventilation noise is one of the dominant noise sources for adjacent buildings, and, therefore, they found that the shorter the distance between the building's fans and ventilation, the more severe the impact of the noise. They also concluded that the noise attenuation rate increases with an increase in the distance to the noise source [51].

Moradi et al. [52] concluded that there were no significant differences in the average time spent on correct answers before and after exposure to noise between extroverted and introverted participants; however, there was a significant difference among extroverts in the average time spent on correct answers before and after exposure to noise. The results showed that introverted participants are more sensitive to noise than extroverts. The most noise-sensitive participants showed greater stimulation during exposure to noise, which led to increases in incorrect responses and a decrease in mental performance. Moradi et al. [52] found that the participants' personal traits are related to their annoyance 
due to noise. Moradi et al. [52] concluded that stress due to noise improves selective attention in extroverted individuals.

Finally, Alves et al. [53] concluded that the "exposed" area has higher sound levels and, consequently, more problems with well-being and health than the "unexposed" population. Audiometric tests also revealed that the "exposed" population seems to be less sensitive to low-frequencies than the "unexposed" population; that is, the "exposed" group needs a higher sound intensity to perceive noise, especially at lower frequencies. The "exposed" group has a larger number of respondents with health problems (e.g., cardiovascular disease, insomnia, and depression), which can be caused by exposure to low-frequency noise emitted by power poles and lines. On the other hand, the "unexposed" group tends to perceive noise with a slightly lower sound intensity, due to the fact that this residential area is far from the emission source [53].

\subsection{Annoyance}

Annoyance is another effect on human health due to exposure to low-frequency noise.

Boyle et al. [54] assessed how the A-weighted exposure levels differed indoors and outdoors in homes in the vicinity of a natural gas compressor station, where low-frequency noise was found. They performed measurements of the noise levels defined in the A-weighted scale to filter most of the low-frequency noise and in the C-weighted scale to identify the impulse noise (noise measured in less than one second with peak levels $15 \mathrm{~dB}$ higher than the background noise) [54].

Van Kamp, Breugelmans, Van Poll, Baliatsas and Van Kempen [40], and Lee et al. [50] presented questionnaires to assess issues related to annoyance due to noise. Van Kamp et al. [40] surveyed complaints due to low-frequency noise using existing data and by means of a questionnaire determining participants' annoyance due to noise from road, rail, and air traffic sources, low-frequency noise, construction noise, and noise sensitivity; the residential satisfaction index; and a survey of measures applied in the residence to avoid noise. As for the study by Lee et al. [50], the methodologies adopted are referenced in Section 3.3.

The methodologies adopted by Blair et al. [46] and Pohl, Gabriel, and Hübner [44] are referenced in Section 3.2 However, according to [46], noise levels above 50 or $60 \mathrm{dBA}$ can cause annoyance.

Ishitake [43] assessed the level of annoyance regarding the source of low-frequency noise generated by wind energy and road traffic noise, by conducting a questionnaire to obtain these perceptions.

According to Hansen et al. [55], the presence of amplitude modulation in wind farm noise results in increased annoyance and possible sleep disruptions. The developed study investigated the prevalence of this characteristic in homes close to the wind farm [55]. In the article by Hansen et al., several important variables were considered, namely, the receiver-source distance, meteorological conditions, and proximity to reflective surfaces, among others.

Moradi et al. [52] assessed the level of selective attention through the DUAF test (test of selective attention, performance capacity, and general performance) and the level of annoyance based on the ISO15666 (International Organization for Standardization, 2003), based on the study sample referenced in Section 3.3.

As for the results, Boyle et al. [54] found that houses located close to a compressor station have higher average noise levels, both indoors and outdoors, than houses located at a distance greater than $300 \mathrm{~m}$. The authors also found that noise levels during the day were higher than those recorded at night and that the residents of residences located less than $300 \mathrm{~m}$ from the station were exposed to low-frequency noise. In this study, they established the relationship of the results with the daytime and nighttime noise levels recommended for the prevention of hearing loss and annoyance, established by the $\mathrm{WHO}[56,57]$, and found that the average noise levels determined exceeded these guidelines [54]. 
Table 1. Studies selected and health effects related to low-frequency noise.

\begin{tabular}{|c|c|c|c|c|c|c|}
\hline \multirow{2}{*}{ Year } & \multirow{2}{*}{ Studies } & \multicolumn{5}{|c|}{ Studies Evaluated } \\
\hline & & $\begin{array}{c}\text { Number of } \\
\text { Participants/Sample }\end{array}$ & Main Human Health Effects & Methodology & Exposure & Outcomes \\
\hline 2016 & $\begin{array}{l}\text { Zeitooni, Mäki-Torkko and } \\
\text { Stenfelt [66] }\end{array}$ & 27 & Binaural hearing capacity & $\begin{array}{l}\text { Evaluation of binaural auditory capacity in adults } \\
\text { with normal hearing when bone conduction } \\
\text { stimulation is applied bilaterally in the bone } \\
\text { conduction hearing aid implant position, as well } \\
\text { as in the audiometric position in the mastoid. }\end{array}$ & $\begin{array}{l}\text { Exposure to } \\
\text { low-frequency noise } \\
(400 \text { to } 600 \mathrm{~Hz}) \text { and } \\
\text { high-frequency noise } \\
(3000 \text { to } 5000 \mathrm{~Hz}) .\end{array}$ & $\begin{array}{l}\text { The results confirmed that the binaural auditory } \\
\text { processing with bilateral bone conduction } \\
\text { stimulation in the mastoid position is also present } \\
\text { in the bone conduction hearing aid (BCHA) } \\
\text { implant position. This indicates the capacity for } \\
\text { binaural hearing in patients with good cochlear } \\
\text { function when using bilateral BCHAs. }\end{array}$ \\
\hline 2016 & $\begin{array}{l}\text { Walker, Brammer, Cherniack, } \\
\text { Laden and Cavallari [63] }\end{array}$ & 10 (male) & Heart rate variability and stress & $\begin{array}{l}\text { The authors conducted a sound monitoring } \\
\text { campaign between February } 2015 \text { and February } \\
2016 \text { across the city of Boston, MA. Boston } \\
\text { occupies an area of } 124 \text { square kilometres with an } \\
\text { estimated population of close to } 7000,000 \\
\text { individuals. To identify potential monitoring } \\
\text { sites, the authors divided the city of Boston into } \\
500 \times 500 \mathrm{~m} \text { grid cells susing ArcGSS. They } \\
\text { constructed a list of all accessible potential sites ( } n \\
=525 \text {, and } 400 \text { site locations were randomly } \\
\text { selected for monitoring by time of day. } \\
\text { Convenience sampling was also conducted in } \\
\text { certain areas of the city to ensure adequate } \\
\text { coverage of varied land use and urban activity. } \\
\text { The participants underwent an outpatient } \\
\text { electrocardiogram. Blood pressure measurements } \\
\text { and saliva samples were collected before, during, } \\
\text { and after exposure to noise. }\end{array}$ & $\begin{array}{l}\text { Low-frequency noise } \\
(31.5 \text { to } 125 \mathrm{~Hz} \text { at } \\
75 \mathrm{~dB}(\mathrm{~A}) ; \\
\text { high-frequency noise } \\
\text { ( } 500 \text { to } 2 \mathrm{kHz} \text { at } 75 \mathrm{~dB} \\
\text { (A)); } 50 \mathrm{~dB}(\mathrm{~A}) \\
\text { "noise-free" exposure. }\end{array}$ & $\begin{array}{l}\text { During exposure to noise, reductions in heart rate } \\
\text { variability of } 19 \%(-35 ;-3.5) \text { with low-frequency } \\
\text { power and } 9.1 \%(-17 ;-1.1) \text { were observed } \\
\text { according to the quadratic difference average } \\
\text { between adjacent normal heartbeat intervals. } \\
\text { During exposure to low-frequency noise, } \\
\text { reductions in heart rate variability of } 32 \%(-57 ; \\
-6.2) \text { with high-frequency power, } 34 \%(-52 ;-15) \\
\text { with low-frequency power and } 16 \% \text { ( }-26 ;-6.1) \\
\text { according to the standard deviation of the } \\
\text { adjacent normal heartbeat intervals. During } \\
\text { exposure to high-frequency noise, reductions in } \\
\text { heart rate variability of } 21 \% \text { (-39; - } 2.3) \text { with } \\
\text { low-frequency power compared to that with } \\
\text { exposure to noise. }\end{array}$ \\
\hline 2016 & $\begin{array}{l}\text { Liu, Young, Yu, Bao and } \\
\text { Chang [67] }\end{array}$ & 1002 & $\begin{array}{l}\text { Hypertension and blood } \\
\text { pressure }\end{array}$ & $\begin{array}{l}\text { Personal noise measurements and environmental } \\
\text { analysis of octave bands were carried out to } \\
\text { divide workers into similar exposure groups } \\
\text { based on the similarity and frequency of the tasks } \\
\text { they performed in the company, thus creating a } \\
\text { high exposure group }((280 \mathrm{dBA}) \text {, another of } \\
\text { medium exposure }(75-79 \mathrm{dBA}) \text {, and another of } \\
\text { low exposure ( }<75 \mathrm{dBA}) \text {. }\end{array}$ & $\begin{array}{l}\text { Noise at frequencies } \\
\text { o } 31.5 \mathrm{~Hz}, 63 \mathrm{~Hz}, 125 \\
\mathrm{~Hz}, 250 \mathrm{~Hz}, 500 \mathrm{~Hz}, 1 \\
\mathrm{kHz}, 2 \mathrm{kHz}, 4 \mathrm{kHz}, \\
\text { and } 8 \mathrm{kHz} \text { during the } \\
\text { working period. }\end{array}$ & $\begin{array}{l}\text { Participants exposed to } \geq 80 \mathrm{dBA} \text { for } 8 \text { years had a a } \\
\text { higher relative risk of hypertension (relative risk } \\
=1.38,95 \% \text { confidence interval: } 1.02,1.85 \text { ) than } \\
\text { those exposed to }<75 \mathrm{dBA} \text {. Significant } \\
\text { exposure-response patterns were observed } \\
\text { between incident hypertension and the stratum of } \\
\text { exposure to noise at frequencies of } 250 \mathrm{~Hz}, 1 \mathrm{kHz} \\
2 \mathrm{kHz}, 4 \mathrm{kHz} \text {, and } 8 \mathrm{kHz} \text {. The strongest effect was } \\
\text { found at the frequency of } 4 \mathrm{kHz} \text {, and a } 20 \mathrm{dBA} \\
\text { increase in noise exposure at } 4 \mathrm{kHz} \text { was found to } \\
\text { be associated with a } 34 \% \text { higher risk of } \\
\text { hypertension (relative risk = } 1.34 \text {, confidence } \\
\text { interval of } 95 \%: 1.01,1.77 \text { ). }\end{array}$ \\
\hline 2016 & Selander et al. [58] & $1,422,333$ & $\begin{array}{l}\text { Hearing dysfunction in } \\
\text { children due to noise during } \\
\text { pregnancy }\end{array}$ & $\begin{array}{l}\text { Occupational noise exposure during pregnancy, } \\
\text { according to the prospective cohort study, FENIX } \\
\text { (foetal noise exposure), based on births between } \\
1986 \text { and 2008. }\end{array}$ & $\begin{array}{l}\text { Low-frequency noise } \\
(<75 \mathrm{dBA}) ; \\
\text { high-frequency noise } \\
(\geq 85 \mathrm{dBA}) ; \\
\text { medium-frequency } \\
\text { noise }(75-84 \mathrm{dBA}) \text {. }\end{array}$ & $\begin{array}{l}\text { In the sample, in a mixture of part-time and } \\
\text { full-time workers during pregnancy, HR adjusted } \\
\text { for hearing impairment associated with exposure } \\
\text { to maternal occupational noise } \geq 85 \text { vs. < } 75 \mathrm{~dB} \\
\text { LAeq, } 8 \mathrm{~h} \text { was } 1.27 \text { ( } 95 \% \text { CI: } 0.991 .64 ; 60 \text { exposed } \\
\text { cases). When restricted to children whose } \\
\text { mothers worked full time and had less than } 20 \\
\text { days of absence during pregnancy, the HR was } \\
1.82 \text { ( } 95 \% \text { CI: } 1.08,3.08 ; 14 \text { exposed cases). }\end{array}$ \\
\hline
\end{tabular}


Table 1. Cont.

\begin{tabular}{|c|c|c|c|c|c|c|}
\hline \multirow{2}{*}{ Year } & \multirow{2}{*}{ Studies } & \multicolumn{5}{|c|}{ Studies Evaluated } \\
\hline & & $\begin{array}{c}\text { Number of } \\
\text { Participants/Sample } \\
\end{array}$ & Main Human Health Effects & Methodology & Exposure & Outcomes \\
\hline 2016 & Abbasi et al. [41] & 53 & $\begin{array}{l}\text { General health; somatic } \\
\text { symptoms; anxiety; insommia; } \\
\text { social dysfunction; depression }\end{array}$ & $\begin{array}{l}\text { Study of the effect of wind turbine noise on the } \\
\text { general health of employees at a wind farm, with } \\
\text { workers divided into three groups: maintenancee } \\
\text { security, and office workers. Equivalent sound } \\
\text { levels were measured for each group. } \\
\text { The individuals' 'health data were assessed using } \\
\text { a } 28 \text {-item questionnaire. Pearson's correlation, } \\
\text { analysis of variance, and multiple regression tests } \\
\text { were performed for data analysis using software. }\end{array}$ & $\begin{array}{l}\text { In the maintenance } \\
\text { team, an LAeq of } 83 \\
\text { dBA was considered, } \\
\text { an LAeq of } 66 \mathrm{dBA} \\
\text { was considered in the } \\
\text { security team, and an } \\
\text { LAeq of } 60 \mathrm{dBA} \text {, } \\
\text { in the administration } \\
\text { team. }\end{array}$ & $\begin{array}{l}\text { Exposure to noise is significantly correlated with } \\
\text { all subscales of general health, except depression. } \\
\text { The low-frequency noise from the turbines can } \\
\text { cause harmful effects on the health of workers } \\
\text { who are very close to the turbine and receive very } \\
\text { intense noise. }\end{array}$ \\
\hline 2016 & Wang et al. [59] & 2700 & $\begin{array}{l}\text { Cardiovascular diseases; } \\
\text { hearing loss. }\end{array}$ & $\begin{array}{l}\text { The authors carried out the study in the } \\
\text { metropolitan area of Taichung, Taiwan and set up } \\
50 \text { monitoring statitons to collect relateded } \\
\text { information on noise measurements, traffic flow } \\
\text { rates, speed limits, and meteorological data. } \\
\text { The } 50 \text { monitoring stations included } 4 \text { agricultural } \\
\text { areas, } 6 \text { green-land areas (e.g., parks, forests, } \\
\text { and mountains), } 2 \text { conservation areass, } 8 \\
\text { culture-educational areas (i.e., schools, temples, } \\
\text { and churches), } 11 \text { residential areas, } 4 \text { industrial } \\
\text { areas, } 1 \text { stream-channel area (e.e.g., harbourss, } 7 \\
\text { commercial areas, } 6 \text { governmental areas (i.e., } \\
\text { governmental agencies and institutes), and } 1 \\
\text { recreational area. } \\
\text { Determination of exposure to traffic noise by } \\
\text { measuring the average equivalent noise levels A } \\
\text { (LAeq, } 24 \text { h) in } 50 \text { monitoring stations ( } 25 \text { road } \\
\text { traffic stations and } 25 \text { non-commercial ones) } \\
\text { covering } 10 \text { different types of land use. }\end{array}$ & $\begin{array}{l}\text { Equivalent } \\
\text { continuous sound } \\
\text { levels (Leq, } 24 \text { h) in } \\
\text { the range of } 30-130 \\
\text { dBA; noise levels with } \\
\text { the time-weighted } \\
\text { average (TWA) at } \\
\text { frequencies of } 31.5,63, \\
125,250,500,1000, \\
2000,4000, \text { and } 8000 \\
\text { Hz. }\end{array}$ & $\begin{array}{l}\text { The Leq annual average, } 24 \mathrm{~h} \text { in Taichung was } \\
66.4 \pm 4.7 \mathrm{dBA} \text {, exceeding the threshold for } \\
\text { cardiovascular disease prevention. The mean } \\
\text { annual Lequ, } 24 \mathrm{~h} \text { in the flow and commercial } \\
\text { channel areas was } 11.2 \pm 1.0 \text { and } 70.0 \pm 2.6 \mathrm{dBA} \text {, } \\
\text { respectively, revealing a potential risk of hearing } \\
\text { loss among residents. The noise levels at } 125 \mathrm{~Hz} \\
\text { had the highest correlation with total traffic and } \\
\text { the highest forecast in multiple linear regression. }\end{array}$ \\
\hline 2017 & $\begin{array}{l}\text { Vasilyeva, Bespalov, Semenov, } \\
\text { Baranenkoand Zinkin [68] }\end{array}$ & 96 rats & $\begin{array}{l}\text { Frequency of chromosomal } \\
\text { aberrations in bone marrow } \\
\text { cells; levels of low molecular } \\
\text { weight DNA (lmwDNA) in } \\
\text { blood plasma. }\end{array}$ & $\begin{array}{l}\text { Exposure to single or multiple LFN from male } \\
\text { Wistar rats and their comparison with those in the } \\
\text { control group. The control group rats were not } \\
\text { subjected to any impact. Measurement of the } \\
\text { frequency of chromosomal aberrations in bone } \\
\text { marrow cells and the levels of lmwDNA in blood } \\
\text { plasma. }\end{array}$ & $\begin{array}{l}\text { Frequency below } 250 \\
\text { Hz; simple LFN with } \\
\text { sound pressure levels } \\
\text { (SPL) of } 120 \mathrm{~dB} ; \\
\text { multiple LFN with } \\
150 \mathrm{~dB} \text { SPL. }\end{array}$ & $\begin{array}{l}\text { Blood plasma lmwDNA levels measured the } \\
\text { following day after a single exposure to LFN were } \\
\text { significantly higher }(7.7 \text { and } 7.6 \text { times, } \\
\text { respectively) than in the control group }(11.0 \pm 5.4 \\
\text { ng/mL), and these levels were higher }(4.8 \text { and } 2.1 \\
\text { times, respectively) in the week after a single } \\
\text { exposure of LFN to the SPL of } 120 \text { and } 150 \mathrm{~dB}, \\
\text { respectively, than in the control group p }(18.8 \pm 1.6 \\
\text { gn/mL). Similar results were obtained in the } \\
\text { group with multiple exposures to LFN ( } 36.4 \text { and } \\
22.4 \text { times, respectively) compared to the control } \\
\text { group }(17.7 \pm 1.7 \mathrm{ng} / \mathrm{mL} L \text { ) and suggest an increase } \\
\text { in cell apoptosis as a result of impact of the LFN }\end{array}$ \\
\hline 2017 & Boyle et al. [54] & 11 & $\begin{array}{l}\text { Noise disturbance from natural } \\
\text { gas compression stations. }\end{array}$ & $\begin{array}{l}\text { Assessment of how A-weighted exposure levels } \\
\text { differ indoors and outdoors in homes near the } \\
\text { natural gas compressor station, where } \\
\text { low-frequency noise was found. Measurement of } \\
\text { noise levels defined in the A-weighted scale to } \\
\text { filter out most of the low-frequency noise and in } \\
\text { the C-weighted scale to identify the impulse noise. }\end{array}$ & - & $\begin{array}{l}\text { Houses located close to a compressor station have } \\
\text { higher average noise levels, both indoors and } \\
\text { outdoors, than houses located more than } 300 \mathrm{~m} \\
\text { away. Noise levels during the day were higher } \\
\text { than at night. Residents of residences located less } \\
\text { than } 300 \mathrm{~m} \text { from the station were exposed to } \\
\text { low-frequency noise. The daytime and nighttime } \\
\text { noise levels recommended for preventing hearing } \\
\text { loss and annoyance were exceeded. }\end{array}$ \\
\hline
\end{tabular}


Table 1. Cont.

\begin{tabular}{|c|c|c|c|c|c|c|}
\hline \multirow{2}{*}{ Year } & \multirow{2}{*}{ Studies } & \multicolumn{5}{|c|}{$\begin{array}{l}\text { Studies Evaluated } \\
\end{array}$} \\
\hline & & $\begin{array}{c}\text { Number of } \\
\text { Participants/Sample }\end{array}$ & Main Human Health Effects & Methodology & Exposure & Outcomes \\
\hline 2017 & $\begin{array}{l}\text { Van Kamp, Breugelmans, Van } \\
\text { Poll, Baliatsas and Van } \\
\text { Kempen [40] }\end{array}$ & 3972 & $\begin{array}{l}\text { Annoyance due to } \\
\text { low-frequency noise }\end{array}$ & $\begin{array}{l}\text { Survey of complaints due to low-frequency noise, } \\
\text { based on analysis of existing data. Conducting a } \\
\text { questionnaire with participants addressing } \\
\text { aspects such as annoyance and sensitivity to } \\
\text { noise, sources of emission, and residential } \\
\text { satisfaction, among others. }\end{array}$ & - & $\begin{array}{l}\text { The level of background noise, sensitivity to noise, } \\
\text { and dissatisfaction with the residential situation } \\
\text { were strongly associated with higher levels of } \\
\text { annoyance. The lower the background noise } \\
\text { levels, the greater the annoyance due to tinnitus. } \\
\text { Low-frequency noise is particularly a problem in } \\
\text { places with low levels of background noise. }\end{array}$ \\
\hline 2017 & $\begin{array}{l}\text { Ohgami, Oshino, Ninomiya, Li } \\
\text { and Kato [60] }\end{array}$ & Rats & Hearing loss; imbalance & $\begin{array}{l}\text { Conducting an experimental study in which wild } \\
\text { type rats were exposed to similar low-frequency } \\
\text { noise and the assessment of noise-induced } \\
\text { hearing loss and determination of the rats' } \\
\text { imbalance. }\end{array}$ & $\begin{array}{l}\text { Low-frequency noise } \\
(70 \mathrm{~dB}, 100 \mathrm{~Hz})\end{array}$ & $\begin{array}{l}\text { The authors observed that a sound stimulation at } \\
375 \mathrm{~Hz} \text { at a frequency lower than the audible } \\
\text { range of the rats causes a hearing reduction in } \\
\text { wild type rats, and in rats with an abnormal } \\
\text { otolytic morphology, this hearing loss was not } \\
\text { observed. }\end{array}$ \\
\hline 2017 & Venet et al. [61] & 117 rats & Effects on hearing & $\begin{array}{l}\text { Evaluation of exposure to the combination of } \\
\text { low-frequency noise and carbon disulfide. }\end{array}$ & $\begin{array}{l}\text { Low-frequency noise, } \\
\text { ranging from } 0.5 \text { to } 2 \\
\mathrm{kHz} \text { at an intensity of } \\
106 \mathrm{~dB} \text { SPL. }\end{array}$ & $\begin{array}{l}\text { Exposure to } \mathrm{CS}_{2}(250 \mathrm{ppm} \text { or more) and noise } \\
\text { increased the extent of the damaged frequency } \\
\text { window, as a significant hearing deficit was } \\
\text { measured at } 9.6 \mathrm{kHz} \text { in these conditions; in } \\
\text { addition, the significance at } 9.6 \mathrm{kHz} \text { increased } \\
\text { with solvent concentrations. Histological data } \\
\text { showed that neither hair cells nor ganglion cells } \\
\text { were damaged by } \mathrm{CS}_{2} \text {. }\end{array}$ \\
\hline 2017 & $\begin{array}{l}\text { Alimohammadi and } \\
\text { Ebrahimi [69] }\end{array}$ & 89 & Mental performance & $\begin{array}{l}\text { All participants underwent the Stroop and } \\
\text { Cognitrone tests in silent conditions, after } 30 \text { min } \\
\text { of exposure to LFN and HFN. The Cognitrone test } \\
\text { assesses concentration and attention, and the } \\
\text { Stroop interference test is a sensorimotor speed } \\
\text { test that records the performance of reading } \\
\text { speed. }\end{array}$ & $\begin{array}{l}\text { Low-frequency and } \\
\text { high-frequency noise } \\
\text { at } 50 \text { and } 70 \mathrm{dBA} \text {. }\end{array}$ & $\begin{array}{l}\text { Both noises emitted (LFN and HFN) not only } \\
\text { caused precision in scaling the response but also } \\
\text { reduced the duration of the test run. It was } \\
\text { concluded that, disregarding the distribution of } \\
\text { energy frequencies, noise improved the task } \\
\text { performance of participants. The results } \\
\text { illustrated that individuals under LFN performed } \\
\text { the Cognitrone test more quickly than individuals } \\
\text { under HFN. }\end{array}$ \\
\hline 2017 & $\begin{array}{l}\text { Huang, Pan, Liu, Hou and } \\
\text { Yang [48] }\end{array}$ & - & Noise disturbance & $\begin{array}{l}\text { Analysis of acoustic comfort and development of } \\
\text { a noise analysis model for a skyscraper, through } \\
\text { the measurement of exterior noise, mainly road } \\
\text { traffic noise. The selection of measuring points } \\
\text { was made on the horizontal and vertical planes } \\
\text { and strictly follows the guidelines (Chinese } \\
\text { standard JTG B03-206 and HJ 2.4-2009). The noise } \\
\text { measurement instruments were an AWA6270+B } \\
\text { noise analyser, AWA6228 frequency analyser, } \\
\text { and TES1350A sound level meter. }\end{array}$ & - & $\begin{array}{l}\text { A higher capacity to respond to high-frequency } \\
\text { than low-frequency mining noise (LF) was } \\
\text { observed, which probably reflects the audibility } \\
\text { of the two frequency spectra. }\end{array}$ \\
\hline 2017 & $\begin{array}{l}\text { Mancera, Lisle, Allavena and } \\
\text { Phillips [70] }\end{array}$ & 57 rats & $\begin{array}{l}\text { Effects on behaviour (stress), } \\
\text { organ morphology, and faecal } \\
\text { corticosterone. }\end{array}$ & $\begin{array}{l}\text { Evaluation of the effects of noise from mining } \\
\text { machines on the behaviour and physiological } \\
\text { parameters (organ morphology and faecal } \\
\text { corticosterone) of wild rats, when subjected to } \\
\text { high- and low-frequency ranges, and comparison } \\
\text { with a reference treatment without auditory } \\
\text { stimuli. }\end{array}$ & $\begin{array}{l}\text { High-frequency noise } \\
(>2 \mathrm{kHz}) ; \\
\text { low-frequency noise } \\
(\leq 2 \mathrm{kHz}) \text {. }\end{array}$ & $\begin{array}{l}\text { The frequencies below and above } 2 \mathrm{kHz} \text { had } \\
\text { differential effects on male and female wild rats } \\
\text { that can have important consequences for their } \\
\text { well-being and survival. }\end{array}$ \\
\hline
\end{tabular}


Table 1. Cont.

\begin{tabular}{|c|c|c|c|c|c|c|}
\hline \multirow{2}{*}{ Year } & \multirow{2}{*}{ Studies } & \multicolumn{5}{|c|}{ Studies Evaluated } \\
\hline & & $\begin{array}{c}\text { Number of } \\
\text { Participants/Sample } \\
\end{array}$ & Main Human Health Effects & Methodology & Exposure & Outcomes \\
\hline 2018 & Morsing et al. [42] & 12 & Sleep effects & $\begin{array}{l}\text { Evaluation of sleep effects, through } \\
\text { polysomnography measurement and } \\
\text { questionnaires, in } 2 \text { pilot studies, due to noise } \\
\text { exposure from wind turbines. Six participants } \\
\text { spent five consecutive nights in an ambient sound } \\
\text { laboratory and, for three nights, were exposed to } \\
\text { the noise of the wind turbine with the variation of } \\
\text { some parameters. }\end{array}$ & $\begin{array}{l}\text { High-frequency (>125 } \\
\text { Hz) and } \\
\text { low-frequency noise } \\
\text { (125 Hz). Similar to a } \\
\text { ventilation noise, } \\
\text { a low background } \\
\text { noise (18dB LAeq) } \\
\text { was used. }\end{array}$ & $\begin{array}{l}\text { During nights with noise from the wind turbine, } \\
\text { there were sleep disturbances compared to during } \\
\text { control nights. Deeper sleep was negatively } \\
\text { affected by higher rotational frequency and } \\
\text { amplitude modulation, but light sleep increased } \\
\text { with high rotational frequency and acoustic beat. }\end{array}$ \\
\hline 2018 & $\begin{array}{l}\text { Blair, Brindley, Dinkeloo, } \\
\text { McKenzie and Adgate [46] }\end{array}$ & 4 (residences) & $\begin{array}{l}\text { Annoyance, sleep disorders, } \\
\text { and cardiovascular effects }\end{array}$ & $\begin{array}{l}\text { Determination of noise levels in a well block of oil } \\
\text { and gas operations of several wells during } \\
\text { construction and drilling in a residential area in } \\
\text { Colorado and the verification of impacts on } \\
\text { human health. A (dBA) and C ( }(\mathrm{dBC}) \text { weighted } \\
\text { noise measurements were collected at four } \\
\text { residences located between } 320(1049.9 \mathrm{ft} \text { and } 550 \\
\mathrm{m}(1804.5 \mathrm{ft} \text { from the site during development } \\
\text { over a three-month period (February to April } \\
\text { 2017). }\end{array}$ & $\begin{array}{l}\text { A and } C \text { weighted } \\
\text { noise levels of } 60.2 \\
\text { dBA and } 80 \mathrm{dBC} \\
\text { respectively. }\end{array}$ & $\begin{array}{l}\text { Proportionally, } 41.1 \% \text { of continuous daytime } \\
\text { equivalent daytime measurements and } 23.6 \% \text { of } 1 \\
\text { min dBA exceeded } 50 \mathrm{dBA} \text {, and } 97.5 \% \text { of daytime } \\
\text { and } 98.3 \% \text { of nighttime measurements exceeded } \\
60 \mathrm{dBC} \text {. Average noise levels in an oil and gas } \\
\text { well during construction and drilling exceed } \\
\text { levels associated with annoyances, sleep } \\
\text { disturbances, and cardiovascular health effects } \\
\text { (greater than } 50 \mathrm{dBA} \text { or } 60 \mathrm{dBC} \text { ) in studies } \\
\text { involving noise sources such as traffic, airports, } \\
\text { wind turbines, and rail-related noise pollution. }\end{array}$ \\
\hline 2018 & $\begin{array}{l}\text { A.M. Abbasi, Motamedzade, } \\
\text { Aliabadi, Golmohammadi } \\
\text { andTapak [71] }\end{array}$ & 35 & $\begin{array}{l}\text { Physiological effects and } \\
\text { mental health (fatigue) }\end{array}$ & $\begin{array}{l}\text { Participants were exposed to low-frequency noise } \\
\text { and were ultimately asked to determine their } \\
\text { level of mental fatigue. A cognitive test was } \\
\text { performed to assess working memory (low, } \\
\text { medium, or high workload). Software was used } \\
\text { to assess mental fatigue, visual fatigue analogue } \\
\text { scale, and psychophysiological indexes. }\end{array}$ & $\begin{array}{l}\text { Low-frequency noise } \\
\text { levels of } 55,65,70, \\
\text { and } 74 \mathrm{dBA} \text {. }\end{array}$ & $\begin{array}{l}\text { The results showed that mental fatigue } \\
\text { significantly affected heart rate, low- to } \\
\text { high-frequency rates, and electroencephalogram } \\
\text { rates. The results confirmed that the mental } \\
\text { fatigue caused by low-frequency noise } \\
\text { significantly impacted the participants' } \\
\text { psychophysiological and working memory with } \\
\text { exposure to noise levels of } 65 \text { to } 75 \mathrm{dBA} \text {. }\end{array}$ \\
\hline 2018 & Ninomiya et al. [72] & 44 rats & Stress & $\begin{array}{l}\text { A comparison of auditory levels and levels of } \\
\text { expression of the Hsp70 protein in the cochlea } \\
\text { was performed between rats exposed and not } \\
\text { exposed to LFN. }\end{array}$ & $\begin{array}{l}\text { Low-frequency noise } \\
\text { (100 Hz to } 95 \mathrm{~dB}) \text {. }\end{array}$ & $\begin{array}{l}\text { The results showed that the inner ear may be one } \\
\text { of the organs negatively affected by the stress } \\
\text { caused by the inaudible exposure to LFN. } \\
\text { Exposure to LFN increases the level of Hsp70 } \\
\text { expression via Cebpb in the inner ear. The levels } \\
\text { of Hsp70 and Cebpb may be candidates for } \\
\text { biomarkers of responses to exposure to LFN. }\end{array}$ \\
\hline 2018 & $\begin{array}{l}\text { Rossi, Prato, Lesina and } \\
\text { Schiavi [65] }\end{array}$ & $\begin{array}{c}25 \\
\text { (19 to } 29 \text { years) }\end{array}$ & $\begin{array}{l}\text { Physiological effects (response } \\
\text { time and heart rate) }\end{array}$ & $\begin{array}{l}\text { The experiment involved } 25 \text { Italian volunteers (12 } \\
\text { female and } 13 \text { male volunteers), aged } 19-29 \text { years. } \\
\text { Before starting the test, each subject filled in a } \\
\text { general questionnaire specifying age, occupation, } \\
\text { musical experience, eyesight and hearing } \\
\text { problems, and the presence of noise in their daily } \\
\text { life. } \\
\text { Measurement of changes in cognitive and } \\
\text { physiological parameters in a sample of } \\
\text { volunteers exposed to three types of noise in a } \\
\text { hemi-anechoic room. Participants were involved } \\
\text { in a cognitive task (Stroop effect) for } 10 \text { min in } \\
\text { four different conditions: silence, multti-tonal } \\
\text { broadband (BBN) stochastic noise, low and } \\
\text { low-frequency stochastic noise (LFN1), } \\
\text { and low-frequency stationary noise with regular } \\
\text { amplitude modulation (LFN2). }\end{array}$ & $\begin{array}{l}\text { Sounds reproduced } \\
\text { with a sound pressure } \\
\text { level equivalent to } 93 \\
\text { dB; BBN noise based } \\
\text { on frequencies } \\
\text { between } 315 \text { and } 2000 \\
\text { Hz; LFN1 with } \\
\text { frequencies between } \\
30 \text { and } 60 \mathrm{~Hz} \text {; LFN2 } 2 \\
\text { with frequencies } \\
\text { between } 30 \text { and } 200 \\
\text { Hz. }\end{array}$ & $\begin{array}{l}\text { In noise conditions, participants reduced their } \\
\text { response times, that is, there was evidence of } \\
\text { increasing stress. Dividing the participants into } \\
\text { extroverts and introverts, it was demonstrated } \\
\text { that LFN1 and LFN2 produced higher stress } \\
\text { effects than BBN noise on cognitive performance } \\
\text { and a physiological stress comparable to that } \\
\text { produced by BBN noise. }\end{array}$ \\
\hline
\end{tabular}


Table 1. Cont.

\begin{tabular}{|c|c|c|c|c|c|c|}
\hline \multirow{2}{*}{ Year } & \multirow{2}{*}{ Studies } & \multicolumn{5}{|c|}{ Studies Evaluated } \\
\hline & & $\begin{array}{c}\text { Number of } \\
\text { Participants/Sample } \\
\end{array}$ & Main Human Health Effects & Methodology & Exposure & Outcomes \\
\hline 2018 & Zhou and Fu [62] & 1404 & $\begin{array}{l}\text { Sensorineural hearing loss } \\
\text { (SNHL); excess bilirubin } \\
\text { (causes problems in the liver, } \\
\text { spleen, kidneys, gallbladder). }\end{array}$ & $\begin{array}{l}\text { Measurements of total serum bilirubin, } \\
\text { tympanometry, and determination of the mean } \\
\text { threshold of pure tones at low frequencies or high } \\
\text { frequencies for a subset of adolescents, to assess } \\
\text { levels of total serious bilirubin associated with } \\
\text { different subtypes of sensorineural hearing loss. }\end{array}$ & $\begin{array}{l}\text { Low-frequency noise } \\
\text { (LPTA: 500, } 1000,2000 \\
\text { Hz); high-frequency } \\
\text { noise (HPTA: } 3000, \\
\text { 4000, 6000, and } 8000 \\
\text { Hz). }\end{array}$ & $\begin{array}{l}\text { Total serum bilirubin levels were associated with } \\
\text { any high-frequency SNHL (HPTA }>15 \mathrm{~dB} \text { in at } \\
\text { least one ear) in addolescents in the USA; } \\
\text { high-frequency SNHL with HPA }>15 \mathrm{~dB} \text { in both } \\
\text { ears (bilateral) or with HPTA } \geq 25 \mathrm{~dB} \text { in at least } \\
\text { one ear had a stronger association with total } \\
\text { serum bilirubin levels than HPTA }>15 \mathrm{~dB} \text { in only } \\
\text { one ear (unilateral) or HPTA }=15-25 \mathrm{~dB} \text { in at least } \\
\text { one ear. }\end{array}$ \\
\hline 2018 & Ishitake [43] & $\begin{array}{c}9000 \\
(\geq 20 \text { years })\end{array}$ & Annoyance; sleep disorders & $\begin{array}{l}\text { Conducting an environmental epidemiological } \\
\text { study and assessing the effects on sleep } \\
\text { disturbance due to low-frequency noise generated } \\
\text { by wind power installations, based on residents } \\
\text { living in areas close to the source. Assessment of } \\
\text { sleep disorders using the Athens Insomnia Scale. } \\
\text { Assessment of environmental noise in residential } \\
\text { areas (50 community centres) close to the noise } \\
\text { source by measuring infrared and low-frequency } \\
\text { sound exposure levels. }\end{array}$ & $\begin{array}{l}\text { Infrared, } \\
\text { low-frequency }(20 \mathrm{~Hz}) \\
\text { and infrasound }(<20 \\
\mathrm{Hz}) \text {. }\end{array}$ & $\begin{array}{l}\text { As for sleep disturbances caused by infrasound } \\
(20 \mathrm{~Hz} \text { or less), the noise level of the wind turbine } \\
\text { measured in the ultra-loww-frequency range is } \\
\text { below the human sensory threshold. Of the } \\
\text { participants, } 63 \% \text { heard the noise when the } \\
\text { distance was less than } 1000 \mathrm{~m} \text {. However, } \\
\text { the hearing rate decreased significantly when the } \\
\text { distance was increased to } 5000 \mathrm{~m} \text {, when only } 2 \% \\
\text { of the participants heard the noise. Based on the } \\
\text { Athens Insomnia Scale, } 40 \% \text { of participants had } \\
\text { sleep disorders when the distance was less than } \\
1000 \mathrm{~m} \text {. However, the frequency of sleep } \\
\text { disorders decreased to } 22 \% \text { with an increase in } \\
\text { distance. Amplitude-modulated sounds and pure } \\
\text { tones contained in the noise generated by wind } \\
\text { power generation facilities tend to increase } \\
\text { annoyance. }\end{array}$ \\
\hline 2018 & Chalansonnet et al. [73] & 133 rats & Balance effects & $\begin{array}{l}\text { Study of how exposure to low-frequency noise } \\
\text { combined with } 250 \text { ppm } \mathrm{CS}_{2} \text { affects rat balance. } \\
\text { Vestibular function was tested based on } \\
\text { post-rotational nystagmus recorded by a } \\
\text { video-oculography system. These measurements } \\
\text { were completed by behavioural tests and } \\
\text { cerebellar analysis to measure levels of gene } \\
\text { expression associated with neurotoxicity. }\end{array}$ & $\begin{array}{l}\text { Low-frequency noise, } \\
\text { ranging from } 0.5 \text { to } 2 \\
\mathrm{kHz} \text { at an intensity of } \\
106 \mathrm{~dB} \text { SPL. }\end{array}$ & $\begin{array}{l}\text { Coexposure to CS-250 ppm and low-frequency } \\
\text { noise reduced the number and duration of the } \\
\text { withdrawals by } 33 \% \text { and } 34 \% \text {, respectively. It was } \\
\text { observed that the effects of Cᄃ } \mathrm{C}_{2} \text { were due to } \\
\text { reversible neurochemical disorders of the efferent } \\
\text { pathways that manage post-rotational nystagmus. } \\
\text { Since the nervous structures that involve } \\
\text { vestibular function seem particularly sensitive to } \\
\mathrm{CS}_{2} \text {, post-rotational nystagmus can be used as an } \\
\text { early non-invasive measure to diagnose } \mathrm{CS}_{2} \\
\text { poisoning as part of an occupational conservation } \\
\text { programme. }\end{array}$ \\
\hline 2018 & Min and Min [74] & $\begin{array}{l}466,822(217,308 \text { with } \\
\text { gastric ulcer }+249,514 \\
\text { with duodenal ulcer })\end{array}$ & $\begin{array}{l}\text { Peptic ulcer (gastric and } \\
\text { duodenal) }\end{array}$ & $\begin{array}{l}\text { Investigation of the incidence of peptic ulcers in } \\
\text { adults due to long-term exposure to } \\
\text { environmental noise. The diagnosis of gastric and } \\
\text { duodenal ulcers was made during an 8-year } \\
\text { follow-up (2006-2013). Environmental noise data } \\
\text { were obtained from the National Noise } \\
\text { Information System, a national noise monitoring } \\
\text { system. }\end{array}$ & $\begin{array}{l}\text { The interquartile } \\
\text { range (IQR) for } \\
\text { nighttime noise } \\
\text { exposure was } 2.37 \mathrm{~dB} \\
\text { for gastric ulcers and } \\
2.41 \mathrm{~dB} \text { for duodenal } \\
\text { ulcers. }\end{array}$ & $\begin{array}{l}\text { Gastric ulcers occurred in } 32.1 \% \text { of individuals, } \\
\text { and duodenal ulcers, in } 10.7 \% \text { of individuals. } \\
\text { The diagnostic rate for gastric and duodenal } \\
\text { ulcers increased with increasing cumulative mean } \\
\text { levels of nighttime ambient noise. With increases } \\
\text { in the IQR of nighttime noise, the risk rate } \\
\text { increased significantly by 12\% for gastric ulcers } \\
\text { and 17\% for duodenal ulcers, based on the fully } \\
\text { adjusted model. }\end{array}$ \\
\hline
\end{tabular}


Table 1. Cont.

\begin{tabular}{|c|c|c|c|c|c|c|}
\hline \multirow{2}{*}{ Year } & \multirow{2}{*}{ Studies } & \multicolumn{5}{|c|}{ Studies Evaluated } \\
\hline & & $\begin{array}{c}\text { Number of } \\
\text { Participants/Sample } \\
\end{array}$ & Main Human Health Effects & Methodology & Exposure & Outcomes \\
\hline 2018 & Pohl, Gabriel and Hübner [44] & $\begin{array}{l}212 \text { (1st phase) and } \\
133 \text { (2nd phase) }\end{array}$ & $\begin{array}{l}\text { General mental indisposition; } \\
\text { reduced performance and work } \\
\text { capacity; lack of concentration; } \\
\text { fatigue; voltage; 位ousness; } \\
\text { dizziness; irritability; } \\
\text { indisposition; reduced sleep } \\
\text { quality; annoyance }\end{array}$ & 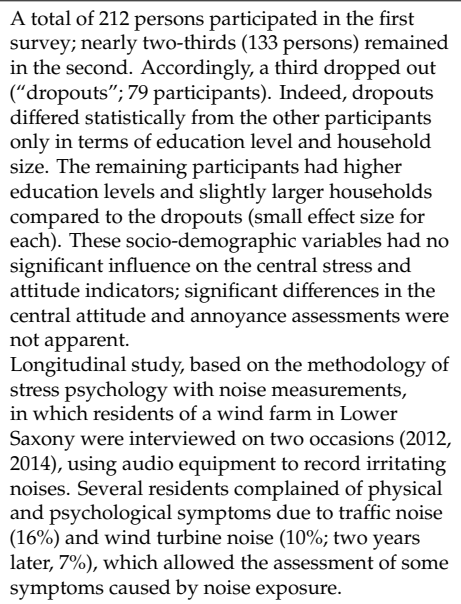 & $\begin{array}{l}\text { Noise from } \\
\text { low-frequency wind } \\
\text { turbines }(<100 \mathrm{~Hz}) .\end{array}$ & $\begin{array}{l}\text { Participants reported more symptoms in } 2012 \\
\text { than in } 2014 \text {. From } 2012 \text { to } 2014 \text {, } 2 \text { sleep disorders } \\
\text { decreased and symptoms of impaired } \\
\text { performance were not repeated. Only a few } \\
\text { participants showed evidence of low-frequency } \\
(<100 \text { Hz) wind turbine (WT) noise effects: in } \\
2012,8.5 \% \text { reported feelings of pressure related to } \\
\text { wind farms and } 6.1 \% \text { experienced vibrations in } \\
\text { the body. The annoyance experienced induced by } \\
\text { feelings of pressure or vibrations was slightly } \\
\text { greater in } 2012 . \text { Symptoms of dizziness were not } \\
\text { observed. The participants had mores symptoms } \\
\text { and greater irritation due to traffic noise than to } \\
\text { wind noise. }\end{array}$ \\
\hline 2018 & $\begin{array}{l}\text { X. Wang, Lai, Zhang and } \\
\text { Zhao [75] }\end{array}$ & $\begin{array}{c}6(3 \text { exposed, } 3 \\
\text { unexposed) Bama } \\
\text { pigs }\end{array}$ & $\begin{array}{l}\text { Effects on the blood-brain } \\
\text { barrier (BBB) }\end{array}$ & $\begin{array}{l}\text { Investigation of the effect of noise exposure on the } \\
\text { blood-brain barrier (BBB.) Healthy male Bama } \\
\text { pigs were randomly divided into noise exposure } \\
\text { group and a control group (no noise) for } 30 \text { min. } \\
\text { After exposure, brain imaging was performed } \\
\text { using computed tomography and fluorescent } \\
\text { images. }\end{array}$ & $\begin{array}{l}\text { Low-frequency noise } \\
(50,70,100, \text { and } 120 \\
\text { Hz at } 140 \mathrm{~dB}) .\end{array}$ & $\begin{array}{l}\text { The BBB permeability test showed that } 50,70, \\
\text { and } 100 \text { Hz noise exposure at } 140 \mathrm{~dB} \text { increased } \\
\text { the BBB permeability, and the BBB opening at } 70 \\
\text { Hz was more severe and reversible. Tomographic } \\
\text { images demonstrated that noise-induced opening } \\
\text { of the BBB did not cause intracerebral } \\
\text { haemorrhage. }\end{array}$ \\
\hline 2018 & $\begin{array}{l}\text { Suzuki, Suzuki, Onishi and } \\
\text { Penido [49] }\end{array}$ & 110 & Tinnitus and LFN discomfort & $\begin{array}{l}\text { Classification of persistent tinnitus and its } \\
\text { comparison with pure tone or noise, high or low } \\
\text { pitch, presented to the patient by the sounds of } \\
\text { the audiometer. Participants were subject to } \\
\text { inclusion and exclusion criteria. The following } \\
\text { evaluations were performed on patients: } \\
\text { otorhinolaryngological, audiological, Pitch } \\
\text { Matching and Loudness, Visual Analogue Scale, } \\
\text { Tinnitus Handicap Inventory, and Minimum } \\
\text { Masking Level. }\end{array}$ & $\begin{array}{l}\text { Three types of noise: } \\
\text { white noise (WN), } \\
\text { narrow band low } \\
\text { frequency (LFNB) at } \\
500 \mathrm{~Hz} \text {, and narrow } \\
\text { band high frequency } \\
\text { (HFNB) at } 6000 \mathrm{~Hz} \text {. }\end{array}$ & $\begin{array}{l}\text { A total of } 181 \text { tinnitus complaints were identified, } \\
\text { in which the presence of pure tone type tinnitus } \\
\text { was observed in } 93 \text { ( } 51 \% \text { ) of the responses ( } 4 \text { from } \\
\text { low pitch and } 89 \text { from high pitch) and from noise } \\
\text { in } 88 \text { ( } 49 \% \text { ) of the responses (15 low frequency } \\
\text { and } 73 \text { high). For tinnitus with low-frequency } \\
\text { sensation, } 19 \text { responses were determined, while } \\
\text { for high-frequency sensation, } 162 \text { responses were } \\
\text { determined. Visual Analogue Scale average of } \\
5.47 \text { for tinnitus similar to pure tone, and } 6.66 \text { for } \\
\text { that similar to noise. Average Loudness for } \\
\text { tinnitus similar to the pure tone of } 12.31 \text { dBNS, } \\
\text { and for that similar to the noise of } 10.54 \text { dBNS. }\end{array}$ \\
\hline
\end{tabular}


Table 1. Cont.

\begin{tabular}{|c|c|c|c|c|c|c|}
\hline \multirow{2}{*}{ Year } & \multirow{2}{*}{ Studies } & \multicolumn{5}{|c|}{$\begin{array}{l}\text { Studies Evaluated } \\
\end{array}$} \\
\hline & & $\begin{array}{c}\text { Number of } \\
\text { Participants/Sample }\end{array}$ & Main Human Health Effects & Methodology & Exposure & Outcomes \\
\hline 2018 & $\begin{array}{l}\text { Paunović, Jakovljević and } \\
\text { Stojanov [76] }\end{array}$ & $\begin{array}{c}112 \\
\text { (82 women and } 30 \\
\text { men, aged } 19 \text { to } 32) .\end{array}$ & $\begin{array}{c}\text { Blood pressure; } \\
\text { haemodynamic events }\end{array}$ & $\begin{array}{l}\text { Study divided into three 10-min phases: resting in } \\
\text { quiet conditions before noise, exposure to traffic } \\
\text { noise, and resting in quiet conditions after noise. } \\
\text { Measurement of blood pressure, heart rate, } \\
\text { and haemodynamic parameters (cardiac index } \\
\text { and total peripheral resistance) with a chest } \\
\text { bioimpedance device. Use of four statistical } \\
\text { models to answer the study questions. }\end{array}$ & $\begin{array}{l}\text { Exposure to noise: } \\
\text { resting in quiet } \\
\text { conditions before } \\
\text { noise (Leq = } 40 \mathrm{dBA}) ; \\
\text { exposure to noise } \\
\text { registered in traffic } \\
\text { (Leq = } 89 \mathrm{dBA}) ; \\
\text { resting in quiet } \\
\text { conditions after noise } \\
\text { (Leq = } 40 \mathrm{dBA}) \text {. }\end{array}$ & $\begin{array}{l}\text { Blood pressure decreased during the quiet phase } \\
\text { before noise, increased in the first minute of } \\
\text { exposure to noive, then gradually decreased at the } \\
\text { end of exposure to noise, and continued to } \\
\text { decrease to baseline values after exposure to noise } \\
\text { The cardiac index showed a gradual decrease } \\
\text { throughout the experiment, while the total } \\
\text { vascular resistance increased steadily during and } \\
\text { after exposure to noise. }\end{array}$ \\
\hline 2019 & Negishi-Oshino et al. [77] & Rats & $\begin{array}{l}\text { Irreversible imbalance with } \\
\text { structural damage to the } \\
\text { otoconial membrane }\end{array}$ & $\begin{array}{l}\text { Assessment of rats' imbalance due to acute } \\
\text { exposure to LFN. The exposed rats also showed } \\
\text { decreased cervical vestibular evoked myogenic } \\
\text { potential (cVEMP) with impaired vestibular hair } \\
\text { cell activity. }\end{array}$ & $\begin{array}{l}\text { LFN with a frequency } \\
\text { of } 100 \mathrm{~Hz} \text { at } 85,90 \text {, or } \\
95 \mathrm{~dB} \text {. }\end{array}$ & $\begin{array}{l}\text { The results of this study demonstrate that acute } \\
\text { exposure to LFN at } 100 \mathrm{~Hz} \text { at } 95 \mathrm{~dB} \text { for just } 1 \mathrm{~h} \\
\text { caused irreversible imbalance in rats with } \\
\text { structural damage to the otoconial membrane, as } \\
\text { the target region for the LFN-mediated imbalance } \\
\text { which could be rescued by Hsp } 70 \text {. }\end{array}$ \\
\hline 2019 & $\begin{array}{l}\text { Lee, Park, Jeong, Choung and } \\
\text { Kim [50] }\end{array}$ & 400 & $\begin{array}{l}\text { Discomfort and sensitivity to } \\
\text { noise; blood pressure; } \\
\text { annoyance due to noise }\end{array}$ & $\begin{array}{l}\text { The study recruited healthy residents aged } \\
\text { between } 20 \text { and } 60 \text { years. fffects of exposure to } \\
\text { transport noise on blood pressure in adult } \\
\text { residents of multi-storey residential buildings, } \\
\text { modififaction of the effects of discomfort from and } \\
\text { sensitivity to internal noise, and self-assessed } \\
\text { associations between transport noise and blood } \\
\text { pressure. Measurement of noise levels at the top } \\
\text { of buildings for } 24 \text { h, forecasting the levels of each } \\
\text { unit in the house for different sources and periods } \\
\text { using noise maps. Conducting adjusted linear } \\
\text { regression analysses to estimate associations } \\
\text { between noise exposure levels and systolic blood } \\
\text { pressurer (SBP) and diastolic blood pressure (DBP). } \\
\text { Conducting a questionnaire with questions about } \\
\text { annoyance from and sensitivity to noise and } \\
\text { sociodemographic variables. }\end{array}$ & $\begin{array}{l}\text { Exposure to noise } \\
\text { (Lden, LDay, } \\
\text { and LNight). }\end{array}$ & $\begin{array}{l}\text { General noise (road traffic and rail noise) and } \\
\text { road traffic showed stronger associations with } \\
\text { SBP than with DBP, while rail noise had similar } \\
\text { associations with SBP and DBP. Stronger } \\
\text { associations were estimated for participants who } \\
\text { reported higher ratings of annoyance by internal } \\
\text { noise. The results support the hypothesis that } \\
\text { long-term exposure to transport noise is } \\
\text { associated with higher blood pressure in adults } \\
\text { living in multi-storey residential buildings. }\end{array}$ \\
\hline 2019 & Scherer and Formby [78] & 151 & $\begin{array}{l}\text { Tinnitus retraining therapy } \\
\text { (TRT); sound therapy (ST); } \\
\text { tinnitus-specific educational } \\
\text { counselling (TC) }\end{array}$ & $\begin{array}{l}\text { Comparison of the effectiveness of TRT and its } \\
\text { components, ST and CT, with the standards of } \\
\text { care (SoC) in reducing the negative effect of } \\
\text { tinnitus on quality of life. Study carried out in } 6 \\
\text { military hospitals, in the office and in a data } \\
\text { coordination centre, among active, retired, } \\
\text { and dependent military personnel with } \\
\text { functionally adequate hearing sensitivity and } \\
\text { moderate to severe subjective tinnitus, with the } \\
\text { objective of treating the military. }\end{array}$ & LFN (tinnitus). & $\begin{array}{l}\text { There were few differences between treatment } \\
\text { groups. About half of the participants showed } \\
\text { clinically significant reductions in the effect of } \\
\text { tinnitus. }\end{array}$ \\
\hline
\end{tabular}


Table 1. Cont.

\begin{tabular}{|c|c|c|c|c|c|c|}
\hline \multirow{2}{*}{ Year } & \multirow{2}{*}{ Studies } & \multicolumn{5}{|c|}{ Studies Evaluated } \\
\hline & & $\begin{array}{c}\text { Number of } \\
\text { Participants/Sample }\end{array}$ & Main Human Health Effects & Methodology & Exposure & Outcomes \\
\hline 2019 & Poulsen et al. [45] & $\begin{array}{l}\text { Residences between } \\
20 \text { and } 40 \text { inhabitants }\end{array}$ & $\begin{array}{l}\text { Annoyance; sleep disorders; } \\
\text { depression }\end{array}$ & $\begin{array}{l}\text { Evaluation of the evolution of medical } \\
\text { prescriptions related to anxiolytics and } \\
\text { antidepressants ingested by the populations that } \\
\text { lived near the wind turbines, in an analysis that } \\
\text { lasted two years }(2012 \text { to } 2014 \text { ). } \\
\text { A total of } 7256 \text { wind turnines (WT) was } \\
\text { considered in noise modelling. The authors } \\
\text { collected information on model, type, height, } \\
\text { and operational settings. Each WT was classified } \\
\text { into to one of } 99 \text { noise spectra classes, with } \\
\text { detailed information on the noise spectrum from } \\
10-10,000 \mathrm{~Hz} \text { in thirds of octaves for wind speeds } \\
\text { of } 4-25 \mathrm{~m} / \mathrm{s} \text {. }\end{array}$ & $\begin{array}{l}\text { Exposure to outdoor } \\
\text { wind turbine noise } \\
\text { (WTN) at night }(<24, \\
24 \text { to }<30,30 \text { to }<36, \\
36 \text { to }<42 \text {, and } \geq 42 \mathrm{~dB}) \\
\text { and nighttime low } \\
\text { frequency indoor } \\
\text { WTN }(<5,5 \text { to }<10.10 \\
\text { and }<15 \text {, and } \geq 15 \mathrm{~dB}) \text {. }\end{array}$ & $\begin{array}{l}\text { High levels of outdoors WTN associated with use } \\
\text { of anxiolytics and antidepressants among the } \\
\text { elderly, suggesting that WTN may be potentially } \\
\text { associated with sleep and mental health. }\end{array}$ \\
\hline 2019 & Tao, Wang, Zou, Li and Luo [51] & 100 & $\begin{array}{l}\text { Irritation and sensitivity to } \\
\text { noise }\end{array}$ & $\begin{array}{l}\text { Assessment of noise irritation in the metro } \\
\text { deposit and the influence of noise in adjacent } \\
\text { residential buildings. Conducting a questionnaire } \\
\text { with people who worked at the metro station and } \\
\text { made field measurements, both at the metro } \\
\text { station and in the adjacent residential buildings. }\end{array}$ & $\begin{array}{l}\text { LFN and HFN }(31.5, \\
63,125,250,500,1000, \\
2000,4000,8000, \\
\text { and } 16,000 \mathrm{~Hz})\end{array}$ & $\begin{array}{l}\text { Of respondents, } 96 \% \text { are disturbed by the noise } \\
\text { and } 31 \% \text { of them feel that the impact of the noise } \\
\text { is serious. They found that there is a problem of } \\
\text { annoyance due to low-frequency noise. } \\
\text { The authors evaluated that the noise level caused } \\
\text { by the fans decreases with the height of the floors } \\
\text { and that the shorter the distance between the } \\
\text { building's fans and ventilation, the more severe } \\
\text { the impact of the noise. They concluded that, } \\
\text { with the increase in the distance to the noise } \\
\text { source, the noise attenuation rate increases. }\end{array}$ \\
\hline 2019 & Poulsen et al. [64] & 717.453 & $\begin{array}{l}\text { Myocardial infarction (MI), } \\
\text { stroke }\end{array}$ & $\begin{array}{l}\text { The authors used the Danish Civil Registration } \\
\text { System to identify the study cohort, defined as all } \\
\text { adults (aged } 25-84 \text { years) who lived in one of } \\
\text { these inclusion dwellings any time between five } \\
\text { years before the erection of the first neighbouring } \\
\text { WT and the end of 2013. } \\
\text { Assessment of the impact of MI and stroke risk } \\
\text { when there is long-term exposure to noise from } \\
\text { wind turbines. Based on hospital and mortality } \\
\text { records, an analysis was made of the number of } \\
\text { cases of myocardial infarction and stroke that } \\
\text { existed in homes located around wind turbines. }\end{array}$ & $\begin{array}{l}\text { Exposure to wind } \\
\text { turbine noise (WTN) } \\
\text { at night outdoors }(\geq 24 \\
\text { dB) and nighttime } \\
\text { low frequency indoor } \\
\text { WTN ( } \geq 5 \text { dB; } 10-160 \\
\text { Hz) }\end{array}$ & $\begin{array}{l}\text { High long-term exposure to noise from wind } \\
\text { turbines is associated with an increase in } \\
\text { myocardial infarction and strokes. }\end{array}$ \\
\hline 2019 & $\begin{array}{l}\text { Hansen, Nguyen, Zajamšek, } \\
\text { Catcheside and Hansen [55] }\end{array}$ & $\begin{array}{c}9 \text { (residences) } \\
\text { A total of } 8716 \text { and } \\
897210 \text { min samples } \\
\text { of outdoor and indoor } \\
\text { data }\end{array}$ & Annoyance & $\begin{array}{l}\text { The outdoor measurements carried out at } 9 \\
\text { different residences located between } 1 \text { and } 9 \mathrm{~km} \\
\text { from the nearest wind turbine of a south } \\
\text { Australian wind farm ( } 37 \text { operational turbines), } \\
\text { each with a rated power of } 3 \text { MWW. The wind farm } \\
\text { is positioned along the top of a ridge, and the } \\
\text { wind turbine hub height relative to the residences } \\
\text { varies between } 85 \text { and } 240 \mathrm{~m} \text {. At all residences, } \\
\text { the indoor measurements were taken in a room } \\
\text { that faced as closely as possible towards the wind } \\
\text { farm and the windows were closed. } \\
\text { The presence of amplitude modulation in the } \\
\text { noise of wind farms results in increased } \\
\text { annoyance and possible interruptions in sleep. } \\
\text { The study investigated the prevalence of this } \\
\text { characteristic present in homes close to the wind } \\
\text { farm. }\end{array}$ & & $\begin{array}{l}\text { During the night, audible amplitude modulation } \\
\text { occurred in homes located } 3.5 \mathrm{~km} \text { from the wind } \\
\text { farm up to } 22 \% \text { of the time. This had important } \\
\text { implications for possible sleep disruptions and } \\
\text { annoyance due to the wind farm by audible } \\
\text { amplitude modelling, particularly as ambient } \\
\text { noise levels in rural South Australia can be as low } \\
\text { as } 15 \text { and } 5 \mathrm{dBA} \text {, outdoors and in closed areas, } \\
\text { respectively. }\end{array}$ \\
\hline
\end{tabular}


Table 1. Cont.

\begin{tabular}{|c|c|c|c|c|c|c|}
\hline \multirow{2}{*}{ Year } & \multirow{2}{*}{ Studies } & \multicolumn{5}{|c|}{ Studies Evaluated } \\
\hline & & $\begin{array}{c}\text { Number of } \\
\text { Participants/Sample } \\
\end{array}$ & Main Human Health Effects & Methodology & Exposure & Outcomes \\
\hline 2019 & $\begin{array}{l}\text { Phadke, Abo-Hasseba, Švec and } \\
\text { Geneid [79] }\end{array}$ & $\begin{array}{l}140 \text { (between } 21 \text { and } \\
56 \text { years) }\end{array}$ & $\begin{array}{l}\text { Voice disorders: dysphonia; } \\
\text { neck pain; vocal effort }\end{array}$ & $\begin{array}{l}\text { This study aimed to identify possible correlations } \\
\text { between the vocal symptoms of teachers and their } \\
\text { perception of noise, the locations of schools, as } \\
\text { well as the locations and conditions of their } \\
\text { classrooms. They carried out a questionnaire, } \\
\text { whose answers were analysed statistically, with } \\
\text { questions about the severity and frequency of } \\
\text { their voice symptoms, noise perception, and the } \\
\text { locations and conditions of their schools and } \\
\text { classrooms. }\end{array}$ & - & $\begin{array}{l}\text { Teachers experienced severe dysphonia, neck } \\
\text { pain, and increased vocal effort with weekly or } \\
\text { daily recurrence. Among the teachers who } \\
\text { participated in the study, } 24.2 \% \text { felt that they were } \\
\text { always in a noisy environment, with } 51.4 \% \text { of the } \\
\text { total participants reporting having to raise their } \\
\text { voices. The most common sources of noise were } \\
\text { student activities and conversations in the } \\
\text { teachers' own classrooms }(61.4 \%), \text { noise from } \\
\text { adjacent classrooms }(52.9 \%) \text {, and road traffic } \\
(40.7 \%) \text {. }\end{array}$ \\
\hline 2019 & $\begin{array}{l}\text { Smith, Ögren, Ageborg Morsing } \\
\text { and Persson Waye [47] }\end{array}$ & 23 & $\begin{array}{l}\text { Disorders in physiological } \\
\text { sleep; heart rate }\end{array}$ & $\begin{array}{l}\text { The study volunteers slept for five nights in a } \\
\text { sound environment laboratory, which was } \\
\text { furnished like a typical apartment. } \\
\text { The participants were instructed to start trying to } \\
\text { fall asleep at } 23: 00 \text { each evening and were woken } \\
\text { with an alarm call at } 07: 00 \text { each morning. } \\
\text { Sleeping at times outside of this } 8 \mathrm{~h} \text { period was } \\
\text { not permitted. Participants could follow their } \\
\text { normal daytime routine but arrived at the } \\
\text { laboratory by } 20: 00 \text { each evening to allow time for } \\
\text { relaxation and the setup of the sleep-measuring } \\
\text { equipment. Caffeine was prohibited after } 15: 00 \\
\text { each day, and alcohol was prohibited at all times. } \\
\text { Evaluation of the effects on physiological sleep } \\
\text { resulting from the exposure of participants to } \\
\text { railway noise for five consecutive nights, using } \\
\text { polysomnography and questionnaires. Heart rate } \\
\text { was measured by electrocardiography. }\end{array}$ & $\begin{array}{l}\text { Frequencies of } 35,40, \\
\text { and } 45 \mathrm{~dB} .\end{array}$ & $\begin{array}{l}\text { No significant differences were found in the } \\
\text { overall structure of sleep disorders between the } \\
\text { reference tests and the } 35 \mathrm{~dB} \text { night tests. } \\
\text { Regarding cardiovascular diseases, they observed } \\
\text { that the noise spectrum with amplitude } \\
\text { frequencies greater than } 100 \mathrm{~Hz} \text { led to increases in } \\
\text { heart rate for noise levels equal to or greater than } \\
35 \mathrm{~dB} \text {. }\end{array}$ \\
\hline 2019 & Zare et al. [80] & 75 & Serum cortisol concentration & $\begin{array}{l}\text { The study aimed to examine the effect of sound } \\
\text { pressure level (SPL) on the serum concentration of } \\
\text { cortisol at three different times during the night } \\
\text { shift, in an industrial and mining company. } \\
\text { Participants were divided into three groups (one } \\
\text { control and two groups of cases, with } 25 \text { each). } \\
\text { Dosimetry was adopted to evaluate SPL } \\
\text { equivalents using a TES-1 } 345 \text { dosimeter. } \\
\text { The serum cortisol concentration was measured } \\
\text { using a radioimmunoassay (RIA) test in the } \\
\text { laboratory. }\end{array}$ & $\begin{array}{l}\text { Exposure levels of } 67, \\
80 \text {, and } 92 \mathrm{~dB} \text {. }\end{array}$ & $\begin{array}{l}\text { The results indicated a downward trend in the } \\
\text { serum cortisol concentration of the three groups } \\
\text { during the night shift. SPL and exposure time } \\
\text { significantly affected cortisol concentration. Age } \\
\text { and body mass index had no significant influence } \\
\text { on the concentration of cortisisol. It was concluded } \\
\text { that an increase in SPL leads to an increase in } \\
\text { serum cortisol concentration. }\end{array}$ \\
\hline
\end{tabular}


Table 1. Cont.

\begin{tabular}{|c|c|c|c|c|c|c|}
\hline \multirow{2}{*}{ Year } & \multirow{2}{*}{ Studies } & \multicolumn{5}{|c|}{ Studies Evaluated } \\
\hline & & $\begin{array}{c}\text { Number of } \\
\text { Participants/Sample }\end{array}$ & Main Human Health Effects & Methodology & Exposure & Outcomes \\
\hline 2019 & Moradi et al. [52] & $\begin{array}{l}28(14 \text { females and } 14 \\
\text { males })\end{array}$ & $\begin{array}{l}\text { Stress; noise sensitivity; } \\
\text { annoyance }\end{array}$ & $\begin{array}{l}\text { The study was conducted on students at different } \\
\text { levels of educational programmes in an acoustic } \\
\text { room in the Schoool of Public Health Iran } \\
\text { University of Medical Sciences, in } 2016 \text {. The study } \\
\text { subjects were comprised of } 14 \text { female and } 14 \text { male } \\
\text { university students who met the following } \\
\text { entrance criteria: normal sense of hearing } \\
\text { (hearingn loss less than } 20 \mathrm{~dB} \text { ) and no sensitivity to } \\
\text { noise. } \\
\text { Study of the effects of noise on selective attention } \\
\text { of university students. They carried out } \\
\text { questionnaires to determine students' personality } \\
\text { traits (extroverted or introverted) and analyse } \\
\text { their stability or instability. Evaluation of the level } \\
\text { of sensitivity to noise, using the Weinstin } \\
\text { sensitivity scale, and the level of selective } \\
\text { attention, using the DUAF test. }\end{array}$ & $\begin{array}{l}80 \mathrm{dBA} \text { noise at } 4000 \\
\mathrm{~Hz} \text { frequency }\end{array}$ & $\begin{array}{l}\text { Introverted participants are more sensitive to } \\
\text { noise than extroverts. The most noise-sensitive } \\
\text { participants showed greater stimulation during } \\
\text { exposure to noise, which led to increases in } \\
\text { incorrect responses and a decrease in mental } \\
\text { performance. The participants' personal traits are } \\
\text { related to their annoyance due to noise. Stress } \\
\text { due to noise improves selective attention in } \\
\text { outgoing individuals. }\end{array}$ \\
\hline 2019 & Alves, Silva and Remoaldo [53] & $\begin{array}{l}200 \text { questionnaires }+ \\
62 \text { measurements of } \\
\text { noise levels }+14 \\
\text { adapted audiometric } \\
\text { tests }\end{array}$ & $\begin{array}{l}\text { Annoyance from LFN; } \\
\text { audibility threshold }\end{array}$ & $\begin{array}{l}\text { Analysis of the effects of exposure to } \\
\text { low-frequency noise pollution, emitted by poles } \\
\text { and power lines, on the well-being of the } \\
\text { population, based on a study of "exposed" and } \\
\text { "unexposed" individuals in two areas. } \\
\text { Conducting audiometric tests adapted to } \\
\text { complement the analysis and determine the } \\
\text { audibility threshold of the volunteers. Sound } \\
\text { level measurement and sound recording (at a } \\
\text { distance of } 5 \mathrm{~m} \text { from the source), as well as the } \\
\text { adapted audiometric performance test. }\end{array}$ & $\begin{array}{l}\text { Frequency range } \\
\text { between } 10 \text { and } 160 \\
\text { Hz }\end{array}$ & $\begin{array}{l}\text { The "exposed" area has higher sound levels and, } \\
\text { consequently, more welfare and health problems } \\
\text { than the "unexposed" population. Audiometric } \\
\text { tests also revealed that the "exposed" population } \\
\text { appears to be less sensitive to low frequencies } \\
\text { than the "unexposed" population. }\end{array}$ \\
\hline
\end{tabular}


Van Kamp et al. [40] explored the determinants of annoyance due to tinnitus, that is, low-frequency noise. This article explored the relationship between contextual, situational, and personal characteristics with the level of annoyance due to low-frequency noise, based on secondary analysis of existing data. The results obtained showed significant differences between cities and neighbourhoods, a significant association between background noise levels during the day, and an inverse effect at night. The level of background noise, sensitivity to noise, and dissatisfaction with the residential situation were strongly associated with higher levels of annoyance. Based on the association with nighttime background levels, it was found that the lower the levels, the greater the annoyance due to tinnitus [40].

The main results of the studies by Blair et al. [46] and Pohl, Gabriel, and Hübner [44] have already been described in Section 3.2. Blair et al. (2018) found that the average noise levels during the construction and drilling of an oil and gas well exceeded the levels associated with health annoyance; that is, they were above $50 \mathrm{dBA}$ or $60 \mathrm{dBC}$ [46]. Pohl, Gabriel, and Hübner [44] found that the annoyance experienced was very low and that symptoms of dizziness were not observed in this study.

Ishitake [43] carried out a study regarding annoyance due to wind energy, with a questionnaire carried out for the analysis. In this survey, it was observed that $81 \%$ answered that they did not feel annoyed due to the generation of wind energy, while $8 \%$ answered that they felt very or a little annoyed [43].

The results related to noise annoyance determined by Moradi et al. [52] and Lee et al. [50] have already been covered in Section 3.3. However, in addition to what was mentioned earlier, Lee et al. [50] concluded that the closest associations between noise exposure and blood pressure were estimated for participants who reported higher classifications of annoyance, irritation, and sensitivity to noise. This indicates that the annoyance from internal noise and sensitivity to noise develop regardless of the level of exposure to external noise. The authors also found that people who were sensitive to noise and participants most irritated due to internal noise had significantly higher SBP and DBP than others [50].

Finally, Hansen et al. [55] determined an audible internal low-frequency tone modulated in amplitude in the frequency of the passage of the blade for $20 \%$ of the time up to a distance of 2.4 $\mathrm{km}$. The audible amplitude modelling took place for a similar percentage of time between the wind farm's percentage power capacities of $40 \%$ and $85 \%$. The modelling of the audible amplitude in the interior still occurred for $16 \%$ of the time at a distance of $3.5 \mathrm{~km}$. At distances of 7.6 and $8.8 \mathrm{~km}$, audible amplitude modelling was only detected on one occasion. During the night, audible amplitude modulation occurred in homes located $3.5 \mathrm{~km}$ from the wind farm up to $22 \%$ of the time. This had important implications for possible sleep disruptions and annoyance due to the wind farm by audible amplitude modelling, particularly as ambient noise levels in rural South Australia can be as low as 15 and $5 \mathrm{dBA}$, outdoors and in closed environments, respectively [55]. Although the geometric dimension of the room was not considered in the study by Hansen et al. [55], it is an important variable for this type of study.

\subsection{Hearing Loss}

Although hearing loss is reported as an effect on human health due to exposure to noise, the studies analysed were not totally conclusive regarding hearing loss due to low-frequency noise.

Selander et al. [58] assessed the impairment of children's hearing when occupational noise exposure occurred during pregnancy. They carried out a prospective cut study and determined cases of hearing impairment in children based on medical records and interviews conducted with prenatal unit teams, in a sample of births between 1986 and 2008 [58]. With the information collected, they established risk models to estimate data related to the impairment of children's hearing when exposed to noise with a strong low-frequency component during pregnancy [58].

Wang et al. [59] evaluated the exposure to noise from traffic and established a comparison regarding the potential risk of hearing loss for residents.

Ohgami, Oshino, Ninomiya, Li, and Kato [60] and Venet et al. [61] addressed experimental studies in rats and the assessment of hearing loss when they are exposed to low-frequency noise. 
Ohgami et al. [60] carried out a survey of experimental studies carried out on rats when exposed to low-frequency noise and made an assessment of associated hearing loss. In this review, the imbalance in rats when exposed to noise was also assessed [60]. However, Venet et al. [61] effectively performed experimental tests on rats, testing the hearing of the rats with equipment (cubic DPOAEs - Distortion product otoacoustic emissions) when the animals were exposed to low-frequency noise combined with carbon disulfide $\left(\mathrm{CS}_{2}\right)$. The rats' hearing was tested before, during, and after exposure to noise, and blood samples were taken to assess the exposure to $\mathrm{CS}_{2}$ [61].

Zhou and $\mathrm{Fu}$ [62] performed measurements to assess levels of total serum bilirubin, performed tympanometry, and examined pure tone thresholds at low or high frequencies associated with adolescents with different subtypes of sensorineural hearing loss (SNHL), using binary or multinomial logistic regression models.

Regarding the results, Selander et al. [58] divided the sample into three parts: (i) mothers who worked full time, (ii) mothers who worked part-time, and (iii) mothers absent from work during pregnancy. They observed an increased risk of hearing impairment in children after exposure to occupational noise during pregnancy. In the sample considered in the study, they determined adjusted risk rates for $75-84 \mathrm{dBA}$ and $\geq 85 \mathrm{dBA}$, compared to $<75 \mathrm{dBA}$, of 1.05 and 1.27 , respectively. They observed 60, 42, and 14 highly exposed cases for all hearing disorders, sensorineural hearing loss, and tinnitus, respectively. They also determined that the adjusted risk rate for exposure to occupational noise $\geq 85 \mathrm{dBA}$ compared to $<75 \mathrm{dBA}$ was 1.82 , based on 14 exposed cases and 2222 cases with low exposure. However, the corresponding relative risks (HR) were 1.25 for high exposure among mothers classified as part-time and 0.74 for women who had more than 153 days of absence from work during pregnancy or who were not working at the time of the interview. Finally, [58] found that, among mothers working full-time, high exposure to occupational noise was associated with an increased risk of hearing impairment. The authors also observed an increase in the risk of hearing impairment of the foetus for the case of mothers who worked part-time. On the other hand, [58] did not find an increased risk of hearing impairment in children whose mothers reported exposure to occupational noise in early pregnancy but were absent from work during pregnancy. Thus, the fact that the mother's risk increases with presence at work proves that occupational noise during pregnancy is associated with an increased risk of hearing impairment in children [58].

Wang et al. [59] observed that the mean annual Leq over $24 \mathrm{~h}$ in the flow and commercial channel areas was $71.2 \pm 1.0$ and $70.0 \pm 2.6 \mathrm{dBA}$, respectively, revealing a potential risk of hearing loss among residents [59].

Ohgami et al. [60] determined that a sound stimulus of $375 \mathrm{~Hz}$, a frequency below the audible range of rats, causes a hearing reduction in wild type rats, while in rats with an abnormal otolytic morphology, no hearing loss was observed.

Venet et al. [61] observed that, after the period of contact with noise, exposure due to noise alone caused a hearing reduction in an area of frequency that varied between 3.6 and $6 \mathrm{kHz}$. The damaged area was approximately one octave $(6 \mathrm{kHz})$ above the highest frequency of the exposure noise $(2.8 \mathrm{kHz})$. Since the maximum auditory sensitivity is located at around $8 \mathrm{kHz}$ in rats, exposure to low-frequency noise can affect the cochlear regions that detect mid-range frequencies. Exposure to $\mathrm{CS}_{2}(250 \mathrm{ppm}$ or more) and noise increased the extent of the damaged frequency window, as a significant reduction in hearing was measured at $9.6 \mathrm{kHz}$ in these conditions, with an increase in $\mathrm{CS}_{2}$ concentrations [61].

Finally, Zhou and Fu [62] determined that total serum bilirubin levels were associated with any subtype of high-frequency sensorineural hearing loss (SNHL). However, they observed that total serum bilirubin levels were not significantly associated with any low-frequency SNHL (bilateral or unilateral; LPTA greater or lesser) [62].

\subsection{Cardiovascular Disease/Heart Rate}

Cardiovascular diseases (variations in heart rate) are another effect on human health due to exposure to low-frequency noise. 
Walker et al. [63] and Smith et al. [47] used electrocardiograms to measure participants' heart rates when they were exposed to low-frequency noise. In the case of [63], participants were also subjected to blood pressure measurements and saliva samples were collected before, during, and after exposure to noise. Based on linear regression models, the differences between the results obtained before, during, and after the noise were examined [63]. In the case studied by Smith et al. [47], the authors measured participants' heart rates when they were exposed to railway noise.

Poulsen et al. [64] assessed the impact of the risk of myocardial infarction and stroke when there is long-term exposure to noise from wind turbines. Based on hospital and mortality records, they analysed the number of cases of myocardial infarction and stroke in homes located around wind turbines [64].

Wang et al. [59] evaluated the exposure to noise from traffic and established a comparison in relation to the prevention threshold established for cardiovascular diseases.

The methodology adopted by Blair et al. [46] has already been referenced in Section 3.2 According to [46], noise levels above 50 or $60 \mathrm{dBA}$ can cause cardiovascular effects.

Rossi et al. [65] measured the changes in cognitive and physiological parameters-in particular, the response time and heart rate-of participants when exposed to tonal noise (silence or multi-band stochastic noise), low-frequency and low-frequency stochastic noise, and low-frequency stationary noise with regular amplitude modulation.

As for the results, Walker et al. [63] concluded that during exposure to noise, the reductions in heart rate variation (HRV) were $19 \%$ with low-frequency power and $9.1 \%$ according to the mean square difference between the intervals of adjacent normal heartbeats (RMSSD). On the other hand, during exposure to low-frequency noise, the reductions in HRV were $32 \%$ with high-frequency power, $34 \%$ with low-frequency power, and $16 \%$ according to the standard deviation of the adjacent normal heartbeat intervals (SDNN). Finally, during exposure to low-frequency noise, the reductions in HRV were $21 \%$ with low-frequency power, compared to that with exposure to noise. As a general conclusion, [63] determined that exposure to noise-and, in particular, low-frequency noise-negatively affects heart rate variation, which affects health in terms of cardiovascular diseases [63].

Part of the results observed by [47] and [46] have already been described in Section 3.2. Regarding cardiovascular diseases, [47] also observed that the noise spectrum with amplitude frequencies greater than $100 \mathrm{~Hz}$ led to increases in heart rate for noise levels equal to or greater than $35 \mathrm{~dB}$ and increasing the probability of excitation at a noise level of $45 \mathrm{~dB}$. Meanwhile, [46] concluded that continuous weighted noise above the $50 \mathrm{dBA}$ threshold can cause health effects, such as an increased risk of cardiovascular disease and hypertension [46].

Wang et al. [59] concluded that the average annual equivalent noise levels (Leq, $24 \mathrm{~h}$ ) were $66.4 \pm 4.7 \mathrm{dBA}$, which exceeded the threshold established for the prevention of cardiovascular diseases.

Rossi et al. [65] concluded that, on average, participants decreased their response times in noise conditions compared to silence conditions; that is, there was evidence of increasing stress, according to the excitation theory. In this study, they observed that participant exposure to low-frequency noise 1 and 2 (LFN1 and LFN2, respectively) produced cognitive stress comparable to stochastic multi-tonal broadband noise (BBN). Subdividing the participants into extroverts and introverts, they demonstrated that LFN1 and LFN2 produced higher stress effects in introverted participants than BBN noise on cognitive performance, but had no effect on extroverts. In addition, heart rates increased significantly in the introverts during the tests, compared to those in a condition of silence before the start of the Stroop effect, while the extroverts showed no changes [65].

Finally, [64] concluded that, for external nighttime noise from long-term-operated wind turbines greater than $42 \mathrm{dBA}$ and low-frequency noise from internal wind turbines greater than $15 \mathrm{dBA}$, the risks were slightly higher for myocardial infarction than those from exposures less than 24 and $5 \mathrm{dBA}$, respectively, but the number of cases was low in the groups with the highest exposure. As for strokes, all low-frequency noise levels from internal wind turbines were associated with adjusted incidence rates close to 1.0, while for noise from external wind turbines, the adjusted incidence rates were greater 
than 1.0 for the groups of intermediate exposure, and lower than the unit for the groups with greater exposure. High long-term exposure to wind turbine noise was associated with slightly elevated point estimates for myocardial infarction, for both exposure to outdoor wind turbine noise and exposure to potentially more biologically relevant indoor wind turbine noise [64].

\section{Conclusions}

In the present research, 39 articles addressing exposure to low-frequency noise and its impacts on human health were analysed in depth. The articles were divided into categories according to the emitting source of the noise, and the effects on human health were addressed. Regarding the emitting source, there was a greater number of articles addressing issues related to environmental noise and wind turbine sources.

As for the effects generated on human health, there was a greater number of articles referring to effects on sleep disorders, discomfort, sensitivity to and irritability from noise, annoyance, hearing loss, and cardiovascular diseases, and these effects were analysed in more detail in this article.

In the case of impacts on sleep disturbance, a dependence on the distance to the source of noise was observed; that is, the greater the proximity to the source, the greater the effects on sleep, as established by [41,43]. With long-term noise exposure, noise sensitivity is lower, which reduces the effects on sleep disturbance, as determined by [44]. Exposure to noise at night disturbs sleep and causes more frequent awakenings, less deep and non-continuous sleep, and morning tiredness in the participants, as discussed by $[42,47]$.

With increasing age, especially for people over the age of 65, exposure to noise causes sleep disturbances, which adds to the demand for sleeping pills and antidepressants, as determined by [45].

According to [46], the average noise levels exceeded the levels for sleep disturbances established for human health.

Discomfort, irritability, and sensitivity to noise were among the effects analysed. Discomfort due to noise depends on the proximity of people to the emitting source, making their sensitivity to noise different. Tao et al. [51] proved that with increased distance from the noise source, the noise attenuation rate increases, due to the fact that they feel uncomfortable and disturbed by the low-frequency noise. Alves et al. [53] observed that constant exposure to noise makes people less sensitive to the perception of noise compared to people who are more distant from the emitting source, necessitating greater sound intensity for the perception of low-frequency noise. This sensitivity of people to noise leads to a decrease in their mental performance, as ascertained by [52], and an increase in blood pressure, especially when people are more irritated, as noted by [50]. Huang et al. [48] observed that the convenience of sound does not increase with distance from the ground for buildings of great height, such as skyscrapers, and that exposure to this noise has an impact on the annoyance and discomfort of its residents. However, Suzuki et al. [49] noted that there was a low percentage of people who were uncomfortable with the presence of low-frequency noise compared to the presence of high-frequency noise.

Background noise levels and sensitivity to noise are associated with higher levels of annoyance; that is, they exceed the thresholds established for this health effect, as indicated by $[40,46,54]$. Moradi et al. [52] also confirms that the level of annoyance when exposed to noise varies with people's personal traits, with greater sensitivity and annoyance in introverts than in extroverts. Exposure to noise from rail transport is associated with the blood pressure of exposed people, which indicates that people with greater sensitivity to noise, greater annoyance, and more irritability have higher blood pressure values than those who do not have these symptoms, as studied by Lee et al. [50]. Thus, the annoyance increases with exposure to noise, especially when people experience unconventional noise. As described by [81], a greater disturbance is observed due to railway noise in people who are not normally exposed to this noise source. Hansen et al. [55] noted that noise levels had implications for annoyance due to exposure to the wind farm. However, both Pohl et al. [44] and Ishitake [43] determined that people do not feel annoyed due to exposure to wind energy noise. New 
methodologies for the evaluation of noise emitted by wind turbines could be used to provide new findings in this field [82].

Exposure to noise causes a potential risk of hearing loss in people subjected to it, as studied by Wang et al. [59] and Venet et al. [61]. Venet et al. [61] also determined that exposure to carbon disulfide $\left(\mathrm{CS}_{2}\right)$ and noise caused a reduction in the auditory level when an increase in $\mathrm{CS}_{2}$ concentrations was observed. Exposure to occupational noise during pregnancy was also a topic studied by Selander et al. [58] who proved that exposure to this type of noise is associated with the risk of increased hearing impairment in children, with greater relevance in mothers who worked full-time and part-time during pregnancy. Through experiments on rats, Ohgami et al. [60] observed a hearing reduction in wild type rats, in contrast to in rats with an abnormal autolytic morphology in which this hearing loss was not observed. However, studies were observed in which no effects associated with hearing loss were found with exposure to low-frequency noise, as ascertained by Zhou and Fu [62]. All studies analysed in this domain regarded low and high frequencies, revealing hearing loss in the samples exposed to high frequencies. Hearing loss due to low-frequency noise was not totally observed.

Finally, it was observed that exposure to noise-in particular, low-frequency noise-negatively affects the variation in heart rate, which harms health in terms of cardiovascular diseases, as it exceeds the levels established for the prevention of these diseases, as discussed by Walker et al. [63], Wang et al. [59], and Blair et al. [46]. According to Rossi et al. [65], heart rate increases significantly in introverts compared to in a situation of silence, while extroverts show no change in their heart rate. Smith et al. [47] realized that the heart rate in people increased with greater exposure to noise. High long-term exposure to noise from wind turbines is associated with an increase in myocardial infarction and stroke, as studied by Poulsen et al. [64].

The literature review carried out constitutes a novelty in Portugal, whether in the social sciences or the more exact ones, such as environmental acoustics. It is expected that in future studies, this type of evaluation can be explored for a longer period and more sources of low-frequency noise emission. This may provide important data on low-frequency exposure and its effects on human health, as well as important information on the definition of limits for installing wind farms and other sources of low-frequency noise. While some type of impacts on health have not yet been analysed and continue to be an understudied field, the impacts studied can provide good advice for the planning field. Thus, these studies can point out good ways of minimising the influence on human beings and can constitute a good tool for the preventive dimension of planning.

Supplementary Materials: The following are available online at http://www.mdpi.com/2076-3417/10/15/5205/s1. A list of 142 references.

Author Contributions: Conceptualization, J.A.A., F.N.P., L.T.S. and P.R.; methodology, J.A.A., F.N.P., L.T.S. and P.R.; results and discussion J.A.A. and F.N.P.; writing and revision of the manuscript, J.A.A., F.N.P., L.T.S. and P.R. All authors have read and agreed to the published version of the manuscript.

Funding: The authors gratefully acknowledge CAPES/Brazil (Process: BEX1684-13/2) for the financial support granted though a doctorate scholarship, the Project Lab2PT-Landscape, Heritage and Territory Laboratory-AUR/04509 and FCT through national funds and, when applicable, the FEDER co-financing, under the new partnership agreement PT2020 and COMPETE2020-POCI 010145 FEDER 007528.

Conflicts of Interest: The authors declare no conflict of interest.

\section{References}

1. Berglund, B.; Hassmén, P.; Job, R.F. Sources and effects of low-frequency noise. J. Acoust. Soc. Am. 1996, 99, 2985-3002. [CrossRef]

2. Pawlaczyk-Łuszczyńska, M.; Dudarewicz, A.; Szymczak, W.; Sliwinska-Kowalska, M. Evaluation of annoyance from low frequency noise under laboratory conditions. Noise Health 2010, 12, 166-181. [CrossRef]

3. Alves, J.A.; Silva, L.T.; Remoaldo, P.C. Impacts of low frequency noise exposure on well-being: A case-study from portugal. Noise Health 2018, 20, 131-145. 
4. Dart, E.E. Effects of high speed vibrating tools on operators engaged in airplane industry. Occup. Med. 1946, 1, 515-550.

5. Rumancev, G.I. Investigations concerning the hygienic evaluation of vibration in factories producing reinforced concrete. Gig. Tr. Prof. Zabol 1961, 5, 6-12.

6. Cohen, A. The influence of a company hearing conservation program on extra-auditory problems in workers. J. Saf. Res. 1976, 8, 146-162.

7. Obata, J.; Morita, S.; Hirose, K.I.; Matsumoto, H. The effects of noise upon human efficiency. J. Acoust. Soc. Am. 1934, 5, 255-261. [CrossRef]

8. Vasudevan, R.; Leventhall, H.G. Annoyance due to environmental low frequency noise and source location-A case study. J. Low Freq. Noise Vib. 1989, 8, 30-39. [CrossRef]

9. Davis, A.C.; Lovell, E.A.; Smith, P.A.; Ferguson, M.A. The contribution of social noise to tinnitus in young people - a preliminary report. Noise Health 1998, 1, 40-46.

10. Mirowska, M. An Investigation and Assessment of Annoyance of Low Frequency Noise in Dwellings. J. Low Freq. Noise Vib. 1998, 17, 119-126. [CrossRef]

11. Rushforth, I.; Moorhouse, A.; Styles, P. A case study of low frequency noise assessed using DIN 45680 Criteria. J. Low Freq. Noise, Vib. Act. Control 2002, 21, 181-198. [CrossRef]

12. Babisch, W.; Ising, H.; Gallacher, J.E.J.; Elwood, P.C. Traffic noise and cardiovascular risk: The Caerphilly study, first phase. Outdoor noise levels and risk factors. Arch. Environ. Health 1988, 43, 407-414. [CrossRef] [PubMed]

13. Bluhm, G.; Eriksson, C. Cardiovascular effects of environmental noise: Research in Sweden. Noise Health 2011, 13, 212-216. [CrossRef] [PubMed]

14. Lundquist, P.; Holmberg, K.; Landstrom, U. Annoyance and effects on work from environmental noise at school. Noise Health 2000, 2, 9-46.

15. Mirowska, M. Evaluation of low frequency noise in dwellings. New Polish recommendations. J. Ofl Low Freq. Noise Vib. 2001, 20, 67-74. [CrossRef]

16. Griefahn, B. Sleep disturbances related to environmental noise. Noise Health 2002, 4, 57-60.

17. Rios, A.L.; Silva, G.A. Sleep quality in noise exposed Brazilian workers. Noise Health 2005, 7, 1-6.

18. Murphy, E.; King, E.A. Scenario analysis and noise action planning: Modelling the impact of mitigation measures on population exposure. Appl. Acoust. 2011, 72, 487-494. [CrossRef]

19. Schultz, T.J. Synthesis of social surveys on noise annoyance. J. Acoust. Soc. Am. 1978, 64, 377-405. [CrossRef]

20. Paulsen, R.; Kastka, J. Effects of combined noise and vibration on annoynce. J. Sound Vib. 1995, 181, $295-314$. [CrossRef]

21. Karpova, N.I.; Alekseev, S.V.; Erokhin, V.N.; Kadyskina, E.N.; Reutov, O.V. Early response of the organism to low-frequency acoustical oscillations. Noise Vib. Bull. 1970, 11, 100-103.

22. Silva, L.T.; Mendes, B.; Rodrigues, D.S.; Ribeiro, P.J.G.; Mendes, J.F.G. A Mobile Environmental Monitoring Station For Sustainable Cities. Int. J. Sustain. Dev. Plan. 2016, 11, 949-958. [CrossRef]

23. Miedema, H.M.E.; Vos, H. Exposure-response relationships for transportation noise. J. Acoust. Soc. Am. 1998, 104, 3432-3445. [CrossRef]

24. Babisch, W. Traffic noise and cardiovascular disease: Epidemiological review and synthesis. Noise Health 2000, 2, 9-32. [PubMed]

25. Passchier-Vermeer, W.; Passchier, W.F. Noise Exposure and Public Health. Environ. Health Perspect. 2000, 108, 123-131. [PubMed]

26. Ising, H.; Kruppa, B. Health effects caused by noise: Evidence in the literature from the past 25 years. Noise Health 2004, 6, 5-13.

27. Bluhm, G.; Berglind, N.; Nordling, E.; Rosenlund, M. Road traffic noise and hypertension. Occup. Environ. Med. 2007, 64, 122-126. [CrossRef] [PubMed]

28. Cavacas, M.A.; Tavares, V.; Oliveira, M.J.; Oliveira, P.; Sezinando, A.; Santos, J.M. Effects of industrial noise on circumpulpar dentin-A field emission scanning electron microscopy and energy dispersive spectroscopy analysis. Int. J. Clin. Exp. Pathol. 2013, 6, 2697-2702.

29. Cavacas, M.A.; Tavares, V.; Borrecho, G.; Oliveira, M.J.; Oliveira, P.; Águas, A.; Santos, J.M. Industrial Noise and Tooth Wear - Experimental Study. Int. J. Med. Sci. 2015, 12, 3-8. [CrossRef]

30. Waye, K.P.; Bengtsson, J.; Kjellberg, A.; Benton, S. Low frequency noise "pollution" interferes with performance. Noise Health 2001, 4, 33-49. 
31. Waye, K.P. On the Effects of Environmental Low Frequency Noise. Ph.D. Thesis, Goteborgs University, Gothenburg, Sweden, 1995.

32. Pawlaczyk-Luszczyńska, M.; Szymczak, W.; Dudarewicz, A.; Sliwiñska-Kowalska, M. Proposed criteria for assessing low frequency noise annoyance in occupational settings. Int. J. Occup. Med. Environ. Health 2006, 19, 185-197. [CrossRef]

33. Leventhall, H.G. Low frequency noise and annoyance. Noise Health 2004, 6, 59-72.

34. Alves, J.A.; Silva, L.T.; Remoaldo, P.C. The influence of Low-frequency noise pollution on the quality of life and place in sustainable cities: A case study from Northern Portugal. Sustainability 2015, 7, 13920-13946. [CrossRef]

35. World Health Organization. Environmental Noise Guidelines for the European Region; WHO Regional Office for Europe: Copenhagen, Denmark, 2018.

36. Laird, D.A. Experiments on the physiological cost of noise. J. Natl. Inst. Ind. Psychol. 1928, 4, $251-258$.

37. Vasudevan, R.N.; Gordon, C.G. Experimental study of annoyance due to low frequency environmental noise. Appl. Acoust. 1977, 10, 57-69. [CrossRef]

38. Castelo Branco, N.A.A. A unique case of vibroacoustic disease. A tribute to an extraordinary patient. Aviat Space Env. Med. 1999, 70, A27-A31.

39. Moorhouse, A.; Waddington, D.; Adams, M. Proposed Criteria for the Assessment of Low Frequency Noise Disturbance; DEFRA: University of Salford: Salford, UK, 2005.

40. Van Kamp, I.; Breugelmans, O.; Van Poll, R.; Baliatsas, C.; Van Kempen, E. Determinants of annoyance from humming sound as indicator of low frequency noise. In Proceedings of ACOUSTICS 2017 Perth: Sound, Science and Society-2017 Annual Conference of the Australian Acoustical Society AAS, Perth, Australia, 19-22 November 2017; pp. 1-7.

41. Abbasi, M.; Monazzam, M.R.; Zakerian, S.A.; Ebrahimi, M.H.; Dehghan, S.F.; Akbarzadeh, A. Assessment of noise effects of wind turbine on the general health of staff at wind farm of Manjil, Iran. J. Low Freq. Noise Vib. Act. Control. 2016, 35, 91-98. [CrossRef]

42. Morsing, J.A.; Smith, M.G.; Ögren, M.; Thorsson, P.; Pedersen, E.; Forssén, J.; Waye, K.P. Wind turbine noise and sleep: Pilot studies on the influence of noise characteristics. Int. J. Environ. Res. Public Health 2018, 15.

43. Ishitake, T. Wind Turbine Noise and Health Effects. Nihon Eiseigaku Zasshi 2018, 73, 298-304. [CrossRef]

44. Pohl, J.; Gabriel, J.; Hübner, G. Understanding stress effects of wind turbine noise-The integrated approach. Energy Policy 2018, 112, 119-128. [CrossRef]

45. Poulsen, A.H.; Raaschou-Nielsen, O.; Peña, A.; Hahmann, A.N.; Nordsborg, R.B.; Ketzel, M.; Brandt, J.; Sørensen, M. Impact of Long-Term Exposure to Wind Turbine Noise on Redemption of Sleep Medication and Antidepressants: A Nationwide Cohort Study. Environ. Heal. Perspect. 2019, 127, 37005. [CrossRef] [PubMed]

46. Blair, B.D.; Brindley, S.; Dinkeloo, E.; McKenzie, L.M.; Adgate, J.L. Residential noise from nearby oil and gas well construction and drilling. J. Expo. Sci. Environ. Epidemiol. 2018, 28, 538-547. [CrossRef]

47. Smith, M.G.; Ögren, M.; Ageborg Morsing, J.; Persson Waye, K. Effects of ground-borne noise from railway tunnels on sleep: A polysomnographic study. Build. Environ. 2019, 149, 288-296. [CrossRef]

48. Huang, B.; Pan, Z.; Liu, Z.; Hou, G.; Yang, H. Acoustic amenity analysis for high-rise building along urban expressway: Modeling traffic noise vertical propagation using neural networks. Transp. Res. Part. D Transp. Environ. 2017, 53, 63-77. [CrossRef]

49. Suzuki, F.A.B.; Suzuki, F.A.; Onishi, E.T.; Penido, N.O. Psychoacoustic classification of persistent tinnitus. Braz. J. Otorhinolaryngol. 2018, 84, 583-590. [CrossRef]

50. Lee, P.J.; Park, S.H.; Jeong, J.H.; Choung, T.; Kim, K.Y. Association between transportation noise and blood pressure in adults living in multi-storey residential buildings. Environ. Int. 2019, 132, 105101. [CrossRef] [PubMed]

51. Tao, Z.; Wang, Y.; Zou, C.; Li, Q.; Luo, Y. Assessment of ventilation noise impact from metro depot with over-track platform structure on workers and nearby inhabitants. Environ. Sci. Pollut. Res. 2019, 26, 9203-9218. [CrossRef]

52. Moradi, G.; Omidi, L.; Vosoughi, S.; Ebrahimi, H.; Alizadeh, A.; Alimohammadi, I. Effects of noise on selective attention: The role of introversion and extraversion. Appl. Acoust. 2019, 146, 213-217. [CrossRef]

53. Alves, J.; Silva, L.T.; Remoaldo, P. How Can Low-Frequency Noise Exposure Interact with the Well-Being of a Population? Some Results from a Portuguese Municipality. Appl. Sci. 2019, 9, 5566. [CrossRef] 
54. Boyle, M.D.; Soneja, S.I.; Quirós-Alcalá, L.; Dalemarre, L.; Sapkota, A.R.; Sangaramoorthy, T.; Wilson, S.; Milton, D.; Sapkota, A. A pilot study to assess residential noise exposure near natural gas compressor stations. PLoS ONE 2017, 12, e0174310. [CrossRef]

55. Hansen, K.L.; Nguyen, P.; Zajamšek, B.; Catcheside, P.; Hansen, C.H. Prevalence of wind farm amplitude modulation at long-range residential locations. J. Sound Vib. 2019, 455, 136-149. [CrossRef]

56. Berglund, B.; Lindvall, T.; Schwela, D.H. Guidelines for Community Noise; World Health Organization: Geneva, Switzerland, 1999.

57. Hurtley, C. (Ed.) Night Noise Guidelines for Europe; WHO Regional Office Europe: Copenhagen, Denmark, 2009.

58. Selander, J.; Albin, M.; Rosenhall, U.; Rylander, L.; Lewné, M.; Gustavsson, P. Maternal occupational exposure to noise during pregnancy and hearing dysfunction in children: A nationwide prospective cohort study in Sweden. Environ. Health Perspect. 2016, 124, 855-860. [CrossRef]

59. Wang, V.-S.; Lo, E.-W.; Liang, C.-H.; Chao, K.-P.; Bao, B.-Y.; Chang, T.-Y. Temporal and spatial variations in road traffic noise for different frequency components in metropolitan Taichung, Taiwan. Environ. Pollut. 2016, 219, 174-181. [CrossRef] [PubMed]

60. Ohgami, N.; Oshino, R.; Ninomiya, H.; Li, X.; Kato, M. Impairments of Inner Ears Caused by Physical Environmental Stresses. Nihon Eiseigaku Zasshi. Jpn. J. Hyg. 2017, 72, 38-42. [CrossRef] [PubMed]

61. Venet, T.; Carreres-Pons, M.; Chalansonnet, M.; Thomas, A.; Merlen, L.; Nunge, H.; Bonfanti, E.; Cosnier, F.; Llorens, J.; Campo, P. Continuous exposure to low-frequency noise and carbon disulfide: Combined effects on hearing. NeuroToxicology 2017, 62, 151-161. [CrossRef] [PubMed]

62. Zhou, G.; Fu, W. Total serum bilirubin levels and sensorineural hearing loss in the US adolescents: NHANES 2007-2010. Int. J. Pediatric Otorhinolaryngol. 2018, 105, 20-26. [CrossRef] [PubMed]

63. Walker, E.D.; Brammer, A.; Cherniack, M.G.; Laden, F.; Cavallari, J.M. Cardiovascular and stress responses to short-term noise exposures-A panel study in healthy males. Environ. Res. 2016, 150, 391-397. [CrossRef] [PubMed]

64. Poulsen, A.H.; Raaschou-Nielsen, O.; Peña, A.; Hahmann, A.N.; Nordsborg, R.B.; Ketzel, M.; Brandt, J.; Sørensen, M. Long-Term Exposure to Wind Turbine Noise and Risk for Myocardial Infarction and Stroke: A Nationwide Cohort Study. Environ. Heal. Perspect. 2019, 2019, 37004. [CrossRef]

65. Rossi, L.; Prato, A.; Lesina, L.; Schiavi, A. Effects of low-frequency noise on human cognitive performances in laboratory. Build. Acoust. 2018, 25, 17-33. [CrossRef]

66. Zeitooni, M.; Mäki-Torkko, E.; Stenfelt, S. Binaural Hearing Ability with Bilateral Bone Conduction Stimulation in Subjects with Normal Hearing: Implications for Bone Conduction Hearing Aids. Ear Hear. 2016, 37, 690-702. [CrossRef]

67. Liu, C.S.; Young, L.H.; Yu, T.Y.; Bao, B.Y.; Chang, T.Y. Occupational noise frequencies and the incidence of hypertension in a retrospective cohort study. Am. J. Epidemiol. 2016, 184, 120-128. [CrossRef] [PubMed]

68. Vasilyeva, I.N.; Bespalov, V.G.; Semenov, A.L.; Baranenko, D.A.; Zinkin, V.N. The Effects of Low-Frequency Noise on Rats: Evidence of Chromosomal Aberrations in the Bone Marrow Cells and the Release of Low-Molecular-Weight DNA in the Blood Plasma. Noise Health 2017, 19, 79-83. [PubMed]

69. Alimohammadi, I.; Ebrahimi, H. Comparison between effects of low and high frequency noise on mental performance. Appl. Acoust. 2017, 126, 131-135. [CrossRef]

70. Mancera, K.F.; Lisle, A.; Allavena, R.; Phillips, C.J.C. The effects of mining machinery noise of different frequencies on the behaviour, faecal corticosterone and tissue morphology of wild mice (Mus musculus). Appl. Anim. Behav. Sci. 2017, 197, 81-89. [CrossRef]

71. Abbasi, A.M.; Motamedzade, M.; Aliabadi, M.; Golmohammadi, R.; Tapak, L. Study of the physiological and mental health effects caused by exposure to low-frequency noise in a simulated control room. Build. Acoust. 2018, 25, 233-248. [CrossRef]

72. Ninomiya, H.; Ohgami, N.; Oshino, R.; Kato, M.; Ohgami, K.; Li, X.; Kato, M. Increased expression level of Hsp70 in the inner ears of mice by exposure to low frequency noise. Hear. Res. 2018, 363, 49-54. [CrossRef]

73. Chalansonnet, M.; Carreres-Pons, M.; Venet, T.; Thomas, A.; Merlen, L.; Seidel, C.; Cosnier, F.; Nunge, H.; Pouyatos, B.; Llorens, J.; et al. Combined exposure to carbon disulfide and low-frequency noise reversibly affects vestibular function. NeuroToxicology 2018, 67, 270-278. [CrossRef]

74. Min, J.Y.; Min, K. Cumulative exposure to nighttime environmental noise and the incidence of peptic ulcer. Environ. Int. 2018, 121, 1172-1178. [CrossRef] 
75. Wang, X.; Lai, Y.; Zhang, X.; Zhao, J. Effect of low-frequency but high-intensity noise exposure on swine brain blood barrier permeability and its mechanism of injury. Neuroscience Letters 2018, 662, 122-128. [CrossRef]

76. Paunović, K.; Jakovljević, B.; Stojanov, V. The timeline of blood pressure changes and hemodynamic responses during an experimental noise exposure. Environ. Res. 2018, 163, 249-262. [CrossRef]

77. Negishi-Oshino, R.; Ohgami, N.; He, T.; Li, X.; Kato, M.; Kobayashi, M.; Gu, Y.; Komuro, K.; Angelidis, C.E.; Kato, M. Heat shock protein 70 is a key molecule to rescue imbalance caused by low-frequency noise. Arch. Toxicol. 2019, 93, 3219-3228. [CrossRef] [PubMed]

78. Scherer, R.W.; Formby, C. Effect of Tinnitus Retraining Therapy vs Standard of Care on Tinnitus-Related Quality of Life: A Randomized Clinical Trial. Jama Otolaryngol. Head Neck Surg. 2019, 145, 597-608. [PubMed]

79. Phadke, K.V.; Abo-Hasseba, A.; Švec, J.G.; Geneid, A. Influence of Noise Resulting From the Location and Conditions of Classrooms and Schools in Upper Egypt on Teachers' Voices. J. Voice 2019, 33, 802.e1-802.e9. [CrossRef] [PubMed]

80. Zare, S.; Baneshi, M.R.; Hemmatjo, R.; Ahmadi, S.; Omidvar, M.; Dehaghi, B.F. The Effect of Occupational Noise Exposure on Serum Cortisol Concentration of Night-shift Industrial Workers: A Field Study. Saf. Health Work 2019, 10, 109-113. [CrossRef] [PubMed]

81. Licitra, G.; Fredianelli, L.; Petri, D.; Vigotti, M.A. Annoyance evaluation due to overall railway noise and vibration in Pisa urban areas. Sci. Total Environ. 2016, 568, 1315-1325. [CrossRef] [PubMed]

82. Iannace, G.; Ciaburro, G.; Trematerra, A. Wind Turbine Noise Prediction Using Random Forest Regression. Machines 2019, 7, 69. [CrossRef]

(C) 2020 by the authors. Licensee MDPI, Basel, Switzerland. This article is an open access article distributed under the terms and conditions of the Creative Commons Attribution (CC BY) license (http://creativecommons.org/licenses/by/4.0/). 